\author{
MARCIN PRZEGIĘTKA \\ https://orcid.org/0000-0002-6185-5497 \\ Instytut Pamięci Narodowej, Warszawa
}

\title{
KONTAKTY POLSKICH I NIEMIECKICH WŁADZ BEZPIECZEŃSTWA W DRUGIEJ POŁOWIE LAT TRZYDZIESTYCH XX WIEKU (KWESTIA ZAGROŻENIA KOMUNISTYCZNEGO)
}

\begin{abstract}
Abstrakt: Podpisanie przez Polskę i Niemcy deklaracji o nieagresji 26 stycznia 1934 r. rozpoczęło nowy rozdział we wzajemnych relacjach, nie oznaczało jednak sojuszu politycznego, ponieważ Warszawa odmawiała udziału w pakcie antykominternowskim. Utrzymywaną w tajemnicy współpracę nawiązały jednak w 1935 r. polskie i niemieckie władze bezpieczeństwa, a jej celem była wymiana informacji o działalności ruchu komunistycznego.
\end{abstract}

Słowa kluczowe: stosunki polsko-niemieckie, polsko-niemiecka współpraca policyjna, Tajna Policja Państwowa, Ministerstwo Spraw Wewnętrznych, III Rzesza, II Rzeczpospolita.
Abstract: The non-aggression declaration signed by Poland and Germany on 26 January 1934 opened a new chapter in mutual relations. It did not, however, mean a political alliance since Warsaw refused the participation in the Anti-Comintern Pact. Nevertheless, in 1935 the Polish and German security forces entered into secret cooperation to exchange information on the activities of the communist movement.

Keywords: German-Polish relations, German-Polish police cooperation, Secret State Police, Ministry of Interior, Third Reich, Second Polish Republic.

Przedmiotem niniejszego studium są kontakty między cywilnymi instytucjami II Rzeczypospolitej i III Rzeszy odpowiedzialnymi za bezpieczeństwo. Po stronie polskiej było to Ministerstwo Spraw Wewnętrznych (MSW), po niemieckiej - Tajna Policja Państwowa (Geheime Staatspolizei, Gestapo). W pewnym zakresie omówione zostaną również kontakty 
między policjami mundurowymi obu państw: Policją Państwową (PP) oraz Policją Porządkową (Ordnungspolizei, Orpo), o ile wiązały się ze zbieraniem informacji na temat ruchu komunistycznego.

\section{Stan badań}

Wprawdzie przedwojenne kontakty między polskimi a niemieckimi instytucjami odpowiedzialnymi za bezpieczeństwo były już przedmiotem zainteresowania historyków, jednak daleko jeszcze do kompleksowego zbadania tej problematyki. Wzmianki na ten temat pojawiały się w historiografii PRL, jednak większość z nich była dość ogólnikowa ${ }^{1}$. Stefania Stanisławska pisała o „niewątpliwie [--] istniejącej [--] współpracy policyjnej Warszawy i Berlina przeciwko ruchowi komunistycznemu", opierając się na notatce ministra spraw zagranicznych Joachima von Ribbentropa z rozmowy z ambasadorem RP w Berlinie Józefem Lipskim z 31 marca 1938 r. $^{2}$ Podobnie dokument ten interpretował Marian Wojciechowski, zwracając jednocześnie uwagę, że kontakty polskich i niemieckich władz bezpieczeństwa nawiązano po zamachu na ministra spraw wewnętrznych Bronisława Pierackiego (15 czerwca 1934 r.) w związku z pościgiem za Mykołą Łebedem [Mikola Lebed'], jednym z organizatorów zamachu i członkiem Organizacji Ukraińskich Nacjonalistów (OUN), który przez Gdańsk usiłował zbiec do Niemiec. Wtedy to Reichsführer SS Heinrich Himmler, a jednocześnie inspektor i zastępca szefa Gestapo (które podporządkowane było wówczas bezpośrednio Hermannowi Göringowi jako premierowi Prus), „zaproponował nawiązanie ścisłej współpracy pomiędzy władzami policyjnymi Polski i Niemiec"3. Gdy Himmler ponowił swoją propozycję, „zawarty został najprawdopodobniej w marcu 1935 r. nieznany niestety z treści układ o współpracy polskich i niemieckich władz bezpieczeństwa, obejmujący współdziałanie i wymianę informacji w zakresie zwalczania ruchu komunistycznego i nacjonalizmu ukraińskiego”4. Ryszard Torzecki uważa, że „nawiązanie

${ }^{1}$ J. Ławnik, Represje policyjne wobec ruchu robotniczego 1918-1939, Warszawa 1979, s. $170-171$.

${ }^{2}$ S. Stanisławska, Warszawska filia antykominternu. Nie opublikowane dokumenty MSZ Polski w sprawie tzw. Ekspozytury Kominternu w Pradze, w: Studia z Najnowszych Dziejów Powszechnych, t. 3, red. K. Lapter i in., Warszawa 1960, s. 242.

${ }^{3}$ M. Wojciechowski, Stosunki polsko-niemieckie 1933-1938, Poznań 1980, s. 230; zob. także: J. Lipski, Diplomat in Berlin 1933-1939. Papers and Memoirs of Józef Lipski, Ambassador of Poland, oprac. W. Jędrzejewicz, New York-London 1968, s. 140.

${ }^{4}$ M. Wojciechowski, op. cit., s. 241-242. 
kontaktów polsko-niemieckich w zakresie walki organów policyjnych przeciwko terrorystom i komunistom" było możliwe dzięki zamachowi na ministra Pierackiego. Badacz ten zaznacza, że „Polska nie dała się sprowokować Himmlerowi i nie podpisała żadnego układu o współpracy z gestapo w sprawie wzajemnych usług", lecz jednocześnie przyznaje, że „wzajemne kontakty między policją obydwu państw istniały”" Okoliczności nawiązania przez ambasadora Lipskiego kontaktu z Himmlerem po zabójstwie Pierackiego oraz zaangażowanie konsula RP w Szczecinie, Heliodora Sztarka, opisał szczegółowo Wojciech Skóra. Potwierdzając fakt zawarcia układu o współpracy policyjnej, dodaje: „Z późniejszej praktyki można wywnioskować, że obejmował on współdziałanie Gestapo i polskiego MSW w zakresie wymiany informacji o ruchu komunistycznym i ukraińskim, głównie z kręgu OUN”. O przesyłaniu „poważnej liczby komunistycznych ulotek" z Warszawy do Berlina wspomina Włodzimierz Borodziej. Zwraca on uwage, że adresatem tych przesyłek był „odpowiedni referat SD [Sicherheitsdienst, Służby Bezpieczeństwa]”, który „nie był w stanie dokonać ich tłumaczenia" z powodu niedoboru personelu o odpowiednich kompetencjach językowych? ${ }^{7}$.

Bogdan Gadomski uzupełnił ustalenia wcześniejszych badaczy o nowe informacje. Ze strony polskiej za kontakty z Niemcami odpowiadało MSW oraz Instytut Naukowego Badania Komunizmu. W Niemczech ich partnerami były Gestapo i Ogólny Związek Niemieckich Stowarzyszeń Antykomunistycznych w Berlinie (Gesamtverband Deutscher antikommunistischer Vereinigungen, Antikomintern). Nawiązana w marcu 1935 r. współpraca sprowadzała się, według Gadomskiego, do wymiany informacji. Za pośrednictwem Ambasady RP w Berlinie przesyłano niemieckim władzom bezpieczeństwa ulotki Komunistycznej Partii Polski (KPP). Za kontakty ze strony polskiej odpowiadał dyrektor departamentu politycznego w MSW, Henryk Kawecki, z kolei w Niemczech w dwóch wypadkach adresatem korespondencji był SS-Gruppenführer Reinhard Heydrich, szef Policji Bezpieczeństwa (Sicherheitspolizei, Sipo - obejmowała Gestapo i Kripo [Kriminalpolizei]) i SD, bliski i zaufany współpracownik Himmlera 8 .

${ }^{5}$ R. Torzecki, Kwestia ukraińska w polityce III Rzeszy (1933-1945), Warszawa 1972, s. 139 i przyp. 19.

${ }^{6}$ W. Skóra, Niemiecki aspekt sprawy zabójstwa ministra Bronisława Pierackiego, „Słupskie Studia Historyczne" 5, 1997, s. 119-137, cytat s. 134.

7 W. Borodziej, Terror i polityka. Policja niemiecka a polski ruch oporu w GG 1939-1944, Warszawa 1985, s. 21.

8 B. Gadomski, Biografia agenta. Józef-Josek Mützenmacher (1903-1947), Warszawa 2009, s. $185-193$. 
$\mathrm{Na}$ zaangażowanie Kaweckiego w kontakty z niemieckimi władzami bezpieczeństwa wskazuje również Andrzej Pepłoński ${ }^{9}$, który twierdzi, że:

Współpraca policji obu państw nie ograniczała się do składania wzajemnych wizyt. Przede wszystkim wymieniano informacje o osobach podejrzanych o działalność wywrotową. W dyspozycji Policji Państwowej znajdował się między innymi „Spis agentów obcych państw poszukiwanych przez defensywę niemiecką", zawierający rejestr osób podejrzewanych o działalność szpiegowską na rzecz ZSRR lub komunistyczną. W innym dokumencie przekazanym przez gestapo figurowało 901 komunistów niemieckich rejestrowanych przez policję Trzeciej Rzeszy. [--] Przedstawione kontakty ułatwiły wywiadowi niemieckiemu dokonanie rozpoznania aparatu policyjnego Drugiej Rzeczypospolitej, a także przygotowanie przyszłej agresji. Świadczą o tym m.in. opublikowane ostatnio badania na temat działalności polskiej policji w okresie okupacji hitlerowskiej ${ }^{10}$.

Z kolei Jerzy W. Borejsza wśród państw, które zawarły „tajne porozumienia o współpracy policyjnej” wymienia tylko Włochy, Węgry i Finlandię, natomiast Polska, Jugosławia i Bułgaria należały do krajów, z którymi jedynie „ustalono konkretną współpracę"11. $\mathrm{Na}$ istnienie polsko-niemieckiej współpracy policyjnej zwracał również uwagę Hans-Adolf Jacobsen $^{12}$. Adam Hempel, badacz dziejów policji granatowej w Generalnym Gubernatorstwie i przedwojennych polsko-niemieckich kontaktów policyjnych, twierdzi, że „pomimo pewnej, zresztą bardzo ograniczonej wymiany doświadczeń z zakresu walki z ruchem komunistycznym", polsko-niemieckie kontakty władz bezpieczeństwa „nie weszły na grunt współpracy ideowo-politycznej"13.

Niektórzy badacze zaprzeczają współpracy polskich i niemieckich władz bezpieczeństwa. Andrzej Misiuk, odnosząc się do ustaleń Wojciechowskiego na temat porozumienia policyjnego, pisał:

${ }^{9}$ A. Pepłoński, Współpraca Policji Państwowej z policjami innych państw w okresie międzywojennym, w: 225 lat policji w Polsce, t. 1: Geneza i ewolucja policji, red. P. Majer, M. Seroka, Olsztyn 2017, s. 195.

10 A. Pepłoński, Policja państwowa w systemie organów bezpieczeństwa Drugiej Rzeczypospolitej, Szczytno 1991, s. 157.

${ }^{11}$ J.W. Borejsza, Rzym a wspólnota faszystowska. O penetracji faszyzmu włoskiego w Europie Środkowej, Południowej i Wschodniej, Warszawa 1981, s. 231.

12 H.-A. Jacobsen, Nationalsozialistische Aussenpolitik 1933-1938, Frankfurt am MainBerlin 1968, s. 462, 829, 834.

13 A. Hempel, Pogrobowcy kleski. Rzecz o policji ,granatowej” w Generalnym Gubernatorstwie 1939-1945, Warszawa 1990, s. 31. 
Stwierdzenie to jest zbyt daleko idące i nie znajduje potwierdzenia w materiale źródłowym. Po pierwsze, wzmianki o rzekomym układzie znajdują się jedynie w źródłach pośrednich (archiwalia służby dyplomatycznej), natomiast w materiałach policyjnych brakuje jakiejkolwiek informacji na ten temat. Po drugie, w okresie międzywojennym rządy państw burżuazyjnych oraz duża część opinii społecznej tych krajów miały negatywny stosunek do komunistów i jedynego państwa komunistycznego - Rosji sowieckiej. Traktowano je jako zagrożenie dla demokracji i bezpieczeństwa na kontynencie europejskim. Dlatego naturalnym zjawiskiem była współpraca służb policyjnych krajów europejskich w tym zakresie. Natomiast nie było w zwyczaju zawieranie jakichkolwiek dwustronnych umów policyjnych ${ }^{14}$.

Podany przez Misiuka argument o zagrożeniu ze strony ZSRS mógłby raczej pośrednio wskazywać na istnienie współpracy policyjnej, niż dowodzić jej braku. Poza tym trudno zgodzić się z tak bezpodstawnym dezawuowaniem znaczenia dokumentów dyplomatycznych w pracy historyka. Trudne do zrozumienia jest ponadto, dlaczego Misiuk nie wziął pod uwagę akt niemieckiej policji.

Stosunkowo liczne są wzmianki w literaturze dotyczące kontaktów między najwyższymi przedstawicielami policji obu państw: komendanta głównego Policji Państwowej Kordiana Józefa Zamorskiego w Niemczech, szefa Orpo SS-Oberrgruppenführera Kurta Daluege i Himmlera. Według Roberta Litwińskiego Zamorski był wyraźnie niechętny zacieśnianiu kontaktów ze stroną niemiecką ${ }^{15}$. Propagandowy wydźwięk podróży Zamorskiego do Niemiec oraz Daluege'a do Polski opisał Eugeniusz Cezary Król ${ }^{16}$. O tych wizytach wspomina również Karol Grünberg ${ }^{17}$.

Szczególne zainteresowanie badaczy budził przyjazd Himmlera do Polski na polowanie w lutym 1939 r. Wydarzenie to analizowali m.in. Marek Kornat, Eugeniusz Cezary Król, Marek Maciejewski, Karina Pryt, Bernard Wiaderny i Stanisław Żerko ${ }^{18}$. Wizyta ta miała istotny wymiar

14 A. Misiuk, Policja Państwowa 1919-1939. Powstanie, organizacja, kierunki działania, Warszawa 1996, s. 188. Por. także: idem, Generat dywizji WP (generalny inspektor PP) Józef Kordian Zamorski. Komendant główny Policji Państwowej (25 I 1935 - IX 1939), w: Komendanci główni polskiej policji (1918-2009), red. P. Majer, Szczytno 2009, s. 64.

15 R. Litwiński, Kordian Józef Zamorski. „Granatowy” generał, Lublin 2018, s. 194-197, 329; idem, Korpus policji w II Rzeczypospolitej. Stużba i życie prywatne, Lublin 2010, s. 332.

${ }^{16}$ E.C. Król, Polska i Polacy w propagandzie narodowego socjalizmu w Niemczech 19191945, Warszawa 2005, s. 149-150.

17 K. Grünberg, SS - czarna gwardia Hitlera, Warszawa 1975, s. 140, 143.

${ }_{18}$ M. Kornat, Polityka zagraniczna Polski 1938-1939. Cztery decyzje Józefa Becka, Gdańsk 2012, s. 298; E.C. Król, op. cit., s. 203; M. Maciejewski, Stosunek Adolfa Hitlera do spraw polskich od zarania nazizmu do jego upadku, „Studia nad Autorytaryzmem i Totalitaryzmem” 
polityczny: odbywała się kilka miesięcy po złożeniu przez ministra von Ribbentropa ambasadorowi Lipskiemu propozycji Gesamtlösung, czyli całościowego uregulowania stosunków polsko-niemieckich (24 X 1938). Jej odrzucenie oznaczało kres dobrych stosunków polsko-niemieckich.

\section{Niemiecka inicjatywa}

Pierwszą próbę nawiązania współpracy z polskimi władzami bezpieczeństwa Niemcy podjęy już trzy dni po rozmowie kanclerza Adolfa Hitlera z posłem Alfredem Wysockim (2 V 1933), która stanowiła pierwszy krok zbliżenia polsko-niemieckiego, zwieńczonego podpisaniem deklaracji o niestosowaniu przemocy (26 I 1934). 5 maja 1933 r. radca Poselstwa Niemiec w Warszawie, Martin Schliep (od 1937 r. kierownik Referatu Politycznego V - Europy Wschodniej w Urzędzie Spraw Zagranicznych), w rozmowie z radcą Włodzimierzem Adamkiewiczem, zastępcą naczelnika Wydziału Zachodniego Ministerstwa Spraw Zagranicznych (MSZ) „prosił w imieniu swego rządu o informację co do liczby komunistów niemieckich, którzy nielegalnie przybyli do Polski. Zarazem prosił o informację, jakie środki do nich są stosowane względnie zamierzone. (Czy też odstawienie do granicy niemieckiej?)"19. Rozmowa ta zakończyła się deklaracją Adamkiewicza, że skieruje on prośbę do „kompetentnego resortu" ${ }^{20}$. Czy sprawa miała dalszy bieg, nie wiadomo.

Rok później, w czasie ścigania zbiegłego do Niemiec współorganizatora zamachu na ministra Pierackiego, Ambasada RP w Berlinie kontaktowała się z Gestapo. Himmler wyraził wtedy chęć nawiązania bezpośredniej współpracy z polskimi organami bezpieczeństwa, bez angażowania pośredników (czyli dyplomacji). Po raz pierwszy zaproponował to 23 czerwca 1934 r. przy okazji omawiania sprawy wydania Łebeda Polsce, ponownie -26 czerwca. Zapewniał przy tym, że po dojściu NSDAP do władzy Niemcy zerwały współpracę z OUN, którą wcześniej wspierały niemieckie koła wojskowe. Było to - jak pisze Skóra - „niezbyt subtelne «przygotowanie podstaw» do zbliżenia”21. Należy zaznaczyć, że

36, 2014, 2, s. 59-60; K. Pryt, Befohlene Freundschaft. Die deutsch-polnischen Kulturbeziehungen 1934-1939, Osnabrück 2010, s. 144, 221; B. Wiaderny, Hans Adolf von Moltke. Eine politische Biographie, Paderborn 2017, s. 104-105; S. Żerko, Stosunki polsko-niemieckie 1938-1939, Poznań 1999, s. 152, 223, 227-230.

19 AAN, Ambasada RP w Berlinie, 395, „Notatka z rozmowy z p. Schliepem z Poselstwa niemieckiego w dn. 5 V 1933 r.", k. 1.

${ }^{20}$ Ibidem.

${ }^{21}$ W. Skóra, op. cit., s. 131-133. 
Himmler mijał się z prawdą. Torzecki dowodził, że w 1933 r. III Rzesza niedwuznacznie zachęcała OUN do podejmowania działalności terrorystycznej na terenie Polski i ZSRS, celem poróżnienia obu tych państw, a pod koniec tego roku w rozmowach z OUN ze strony niemieckiej brała udział nie tylko Abwehra (wywiad wojskowy), lecz również Gestapo ${ }^{22}$. Najpoważniejszym argumentem Himmlera za nawiązaniem współpracy polskich i niemieckich władz bezpieczeństwa miały być planowane przez Ukraińców kolejne zamachy na polskich polityków:

Według jego [tzn. Himmlera - M.P.] wiadomości planowane mają być dwa lub trzy zamachy. Dlatego też uważa on współpracę naszą z jego resortem za pożądaną. Według jego słów najlepiej komunikować się bezpośrednio w takich sprawach, unikając biurokratycznej drogi Auswärtiges Amt. Zapytywał, kto ze strony polskiej byłby odpowiednikiem do Geheime Staatspolizei. Zaznaczył mimochodem, że za jakiś rok będzie miał policję polityczną świetnie zorganizowaną 23 .

Propozycję „porozumienia organów bezpieczeństwa obu państw”24 ambasador Lipski przekazał do Warszawy.

Chociaż Polsce udzielono pomocy w dochodzeniu w sprawie zabójstwa Pierackiego, wkrótce, z powodu nacisków Reichswehry i w związku z nocą długich noży (29/30 VI 1934), w trakcie której rozstrzelano najwyższych dowódców SA, ustały polsko-niemieckie kontakty dotyczące działalności OUN ${ }^{25}$. Na kilka miesięcy zamarły również starania III Rzeszy o nawiązanie stałej współpracy władz bezpieczeństwa obu krajów. Mimo to ambasador Lipski nie zapomniał o tym epizodzie. Jesienią 1934 r. o kwestii „ewentualnej wymiany zdań między przedstawicielami władz polskich i niemieckich na temat terrorystów ukraińskich na terenie Rzeszy oraz akcji wywrotowej komunistycznej” rozmawiał „z przejeżdżającym przez Berlin w drodze do Nauheim dyrektorem Kaweckim z Ministerstwa Spraw Wewnętrznych. Wobec niewyjaśnionej wówczas jeszcze sytuacji [--] między organami Reichswehry a Geheime Staatspolizei odradzałem to spotkanie, licząc, że nadejdzie lepszy ku temu moment" ${ }^{26}$.

${ }^{22}$ R. Torzecki, op. cit., s. 128-129.

${ }^{23}$ AAN, Ambasada RP w Berlinie, 3679, Odpis raportu J. Lipskiego dla J. Becka i T. Schaetzla, 27 VI 1934, k. 33-34.

${ }^{24}$ Notatka ambasadora $w$ Berlinie na temat morderstwa ministra Pierackiego (b.d., 1934?), w: Polskie dokumenty dyplomatyczne. 1934, red. S. Żerko, współpraca P. Długołęcki, Warszawa 2014, dok. 348, s. 816; J. Lipski, op. cit., s. 140; M. Wojciechowski, op. cit., s. 230.

${ }^{25}$ W. Skóra, op. cit., s. 133.

${ }^{26}$ AAN, Ambasada RP w Berlinie, 3679, Odpis pisma J. Lipskiego do T. Schaetzla, 13 II 1935, k. 88. 
Po zamachu w Marsylii w październiku 1934 r., w którym zginęli król Jugosławii Aleksander i francuski minister spraw zagranicznych Louis Barthou, Lipski spotkał się z ministrem spraw zagranicznych Rzeszy Konstantinem von Neurathem. Polski ambasador zwrócił uwage na „niebezpieczeństwo tolerowania tego rodzaju działań, wysuwając myśl pewnego współdziałania dla uchronienia się od podobnych terrorystycznych najść, mogących zakłócić nawet dobre międzypaństwowe stosunki". Chociaż - jak pisał Lipski - spotkało się to ze zrozumieniem ze strony Urzędu Spraw Zagranicznych ${ }^{27}$, nie dyplomacja miała odegrać decydującą rolę w tej dziedzinie.

W styczniu 1935 r. w Polsce gościł Göring, premier Prus i minister lotnictwa Rzeszy (wcześniej nadzorujący również Gestapo w Prusach; od jesieni 1934 r. Gestapo kontrolował już niepodzielnie Himmler), któremu Hitler powierzył opiekę nad relacjami z Polską i który kilkukrotnie w latach 1935-1938 proponował polskim politykom sojusz antysowiecki czy wręcz podział stref interesów na terenie ZSRS ${ }^{28}$. Rozmawiał m.in. z ministrem spraw wewnętrznych Marianem Zyndramem-Kościałkowskim o przeciwdziałaniu terroryzmowi ukraińskiemu ${ }^{29}$. Niedługo później, w lutym 1935 r., Himmler wystąpił ponownie z propozycją nawiązania „współpracy pomiędzy polskimi i niemieckimi władzami bezpieczeństwa w kwestii zwalczania ruchu komunistycznego i terrorystów ukraińskich"30. Lipski pisał do Tadeusza Schaetzla, wicedyrektora Departamentu Politycznego MSZ:

obecnie miałem możność rozmawiania na te tematy z Himmlerem, który sam zaczął się wypytywać o proces przeciwko zabójcy śp. ministra Pierackiego, i doszliśmy wspólnie do przekonania, że kontakty naszych władz bezpieczeństwa byłyby pożądane. Himmler wyobraża sobie to w ten sposób, że nastąpiłby przyjazd jednego z naszych urzędników do Berlina, a następnie wyjazd jednego $z$ ich ludzi do Warszawy ${ }^{31}$.

Himmler zażyczył sobie, aby przedstawiciel polskich władz bezpieczeństwa, który zostanie w sprawie współpracy wydelegowany do Berlina, był aryjczykiem i nie należał do masonerii ${ }^{32}$. O propozycji współdziałania

${ }^{27}$ Ibidem.

${ }_{28}$ S. Żerko, Polska, Niemcy i geneza II wojny światowej, „Przegląd Zachodni” 2009, 2, s. $24-25$.

${ }^{29}$ W. Skóra, op. cit., s. 133.

${ }^{30}$ M. Wojciechowski, op. cit., s. 241-242.

31 AAN, Ambasada RP w Berlinie, 3679, Odpis pisma J. Lipskiego do T. Schaetzla, 13 II 1935, k. 89.

${ }^{32}$ W. Skóra, op. cit., s. 134. 
Lipski poinformował 9 lutego Józefa Becka, a dzień później również szefa Oddziału II Sztabu Głównego, płka Jerzego Englischa. Ten ostatni zawiadomił następnie Lipskiego, że do Berlina na rozmowy z Himmlerem zamierza wydelegować mjra Stanisława Szalińskiego, szefa Wydziału IIb (kontrwywiad) Wydziału Wywiadowczego Oddziału II Sztabu Głównego ${ }^{33}$. Ostatecznie to jednak nie oficer „dwójki” reprezentował Polskę. Jak wynika z korespondencji Lipskiego i Schaetzla, pod uwagę brano również Kaweckiego ${ }^{34}$. Lipski pisał:

Sugestia wysłania mjr. Szalińskiego, a nie dyrektora Kaweckiego, wyszła z Warszawy od [Oddziału II] Sztabu [Głównego - M.P.]. Jeśli chodzi o moją ocenę, to zależy mi przede wszystkim na tym, by dana osoba posiadała znajomość spraw ukraińskich i komunistycznych i to nie tylko teoretycznie, ale i dysponowała danymi faktycznymi. Ponieważ Geheime Staatspolizei jest organizacją raczej cywilną, a nie wojskową, to ze względu na to, jak i z uwagi na pewne reperkusje $\mathrm{w}$ razie ujawnienia spotkań, przychylam się raczej do poglądu Pana Ministra, iż lepiej byłoby wydelegować przedstawiciela M.[inisterstwa] S.[praw] Wewn.[ętrznych] $]^{35}$.

Z listu Lipskiego wynika jasno, że fakt utrzymywania kontaktów przez władze bezpieczeństwa obu państw miał pozostać w ścisłej tajemnicy. Himmler zaproponował spotkanie z przedstawicielem władz polskich między 6 a 8 marca 1935 r. Ambasador RP w Berlinie przypuszczał, że „pierwsze spotkanie byłoby nawiązaniem kontaktu i wymianą myśli na tematy ukraińskie i komunistyczne" 36 .

\section{Polska odpowiedź}

Jak już wspomniano, właśnie z wizytą Kaweckiego w Berlinie w marcu 1935 r. historycy wiążą zawarcie porozumienia o współpracy policyjnej między Polską a Niemcami ${ }^{37}$. Poruszana na tym spotkaniu problematyka i treść porozumienia nie są jednak znane. Pewne wnioski na ten temat

33 AAN, Ambasada RP w Berlinie, 3679, Odpis pisma J. Lipskiego do T. Schaetzla, 13 II 1935, k. 89.

34 AAN, Ambasada RP w Berlinie, 3679, List T. Schaetzla do J. Lipskiego, 18 II 1935, k. 91-92.

35 AAN, Ambasada RP w Berlinie, 3679, Odpis pisma J. Lipskiego do T. Schaetzla, 19 II $1935, \mathrm{k} .86$.

${ }^{36}$ AAN, Ambasada RP w Berlinie, 3679, Odpis pisma J. Lipskiego do T. Schaetzla, 13 II 1935, k. 90.

37 B. Gadomski, op. cit., s. 192; W. Skóra, op. cit., s. 134; M. Wojciechowski, op. cit., s. 241-242. 
można jednak wysnuć z charakteru późniejszych kontaktów między polskimi i niemieckimi władzami bezpieczeństwa. Wydaje się, że sprawy ukraińskie ${ }^{38}$ - chociaż właśnie w konsekwencji działalności OUN współpracę zainicjowano - zeszły na drugi plan, a prym wiodła tematyka komunistyczna. Już od końca marca 1935 r. MSW przekazywało stronie niemieckiej informacje o działalności KPP. Co kilka tygodni wysyłano do Ambasady RP w Berlinie korespondencję, prosząc o przekazanie jej właściwemu adresatowi, czyli Gestapo. Działalność tę kontynuowano do lata 1939 r. ${ }^{39}$ Pierwsze pismo przewodnie skierowane do ambasadora Lipskiego miało następującą treść:

Powołując się na porozumienie z Panem Dyrektorem Dep.[atramentu] Politycznego MSWewn. [Henrykiem Kaweckim - M.P.] w znanej sprawie Panu Ambasadorowi, Ministerstwo Spraw Wewnętrznych przesyła 3 paczki zawierające wydawnictwa kompartii polskiej i prosi uprzejmie o zarządzenie doręczenia przez gońca ewent.[ualnie] inną drogą pod wskazanym na wewnętrznym opakowaniu adresem ${ }^{40}$.

Na piśmie tym zachował się odręczny dopisek urzędnika ambasady: „Wobec urlopu p. [Heinricha] Müllera, wręczyłem osobiście paczki jego zastępcy w Gestapo - Kriminalpolizeirat Heller ${ }^{41}, 1$ IV [19]35"42. Wynika z tego, że kontakty z władzami niemieckimi nadzorował Kawecki, a adresatem części przesyłek był kierownik wydziału II A, czyli komórki Gestapo zajmującej się zwalczaniem ruchu komunistycznego ${ }^{43}$. Przynajmniej raz

${ }^{38} \mathrm{Z}$ niemieckimi władzami policyjnymi kontaktowano się w sprawie Ukraińców podejrzewanych przez władze polskie o działalność terrorystyczną, zachowała się np. część korespondencji w sprawie ustalenia przez Gestapo miejsca pobytu Pawła Turuły, Ukraińca podejrzewanego o udział w zamachu na Pierackiego. Funkcjonariusz berlińskiej centrali Gestapo, Heinz Jost, poinformował, że poszukiwany przebywa w Monachium, gdzie zamierza podjąć studia. AAN, Ambasada RP w Berlinie, 3679, Odpis listu J. Lipskiego do H. Kaweckiego, 9 V 1936, k. 1-3; ibidem, Pismo funkcjonariusza Gestapo, H. Josta, do ambasadora RP w Berlinie, J. Lipskiego, 2 V 1936, k. 4.

39 B. Gadomski, op. cit., s. 192.

40 AAN, Ambasada RP w Berlinie, 398, Pismo naczelnika Wydziału w MSW, St. Kucharskiego, do Ambasadora RP w Berlinie, J. Lipskiego, 26 III 1935, k. 10.

${ }^{41}$ Radca kryminalny Reinhold Heller specjalizował się w zwalczaniu ruchu komunistycznego, jeszcze przed 1933 r. R. Diels, Lucifer ante Portas. Zwischen Severing und Heydrich, Zürich 1949, s. 139; A. Seeger, Vom bayerischen „Systembeamten” zum Chef der Gestapo. Zur Person und Tätigkeit Heinrich Müllers (1900-1945), w: Die Gestapo - Mythos und Realität, red. G. Paul, K.-M. Mallmann, Darmstadt 1995, s. 260.

42 AAN, Ambasada RP w Berlinie, 398, Pismo naczelnika Wydziału w MSW, St. Kucharskiego, do Ambasadora RP w Berlinie, J. Lipskiego, 26 III 1935, k. 10.

${ }^{43}$ J. Bornschein, Gestapo-Müller. Technokrata terroru, Warszawa 2009 (oryg. niem. 2004), s. 29-31. 
ich odbiorcą był Heydrich, szef Sipo i SD ${ }^{44}$. Z czasem informacje w piśmie MSW kierowanym do Ambasady RP w Berlinie z prośbą o dostarczenie przesyłek stały się znacznie bardziej lakoniczne, np.: „Ministerstwo Spraw Wewnętrznych prosi uprzejmie o zarządzenie doręczenia w ustalonej drodze załączonego listu według podanego adresu"45. Ogółem za pośrednictwem Ambasady RP w Berlinie wysłano 91 przesyłek $^{46}$, a pismo z prośbą o doręczenie ostatniej nosi datę 13 lipca 1939 r. ${ }^{47}$ Sprawa korespondencji wysyłanej przez Kaweckiego do Berlina zostanie jeszcze omówiona poniżej.

Ponadto prawdopodobnie właśnie Kaweckiemu w 1935 r. Niemcy przekazali listę poszukiwanych przez Gestapo działaczy komunistycznych. Liczy ona 91 stron i zawiera 901 pozycji. Nazwisk jest jednak mniej, ponieważ część widniejących na niej osób występowała równocześnie pod dwiema lub więcej pozycjami (uwzględniono również pseudonimy, czasem więcej niż jeden). Osoby umieszczone na liście były na ogół członkami KPD lub Kominternu. Przeważają niemieccy komuniści przebywający poza Rzeszą, w tym najbardziej znani: Wilhelm Pieck i Walter Ulbricht ${ }^{48}$ (przy większości nazwisk znajduje się adnotacja o opuszczeniu terytorium Niemiec).

Wbrew informacjom podawanym w dotychczasowych publikacjach ${ }^{49}$, w spisie tym znaleźli się również obcokrajowcy, w tym trzech obywateli polskich: Cyryl Walnicki, poseł na sejm z Ukraińskiego Włościańsko-Robotniczego Zjednoczenia Socjalistycznego (Sel-Rob) ${ }^{50}$, Tadeusz Żarski, nauczyciel, poseł na sejm, członek centralnego komitetu KPP ${ }^{51}$, notabene rozstrzelany w Moskwie w 1934 r., i Julian Leszczyński-Leński, członek

${ }^{44}$ B. Gadomski, op. cit., s. 192. Heydrich był adresatem korespondencji wysyłanej 3 kwietnia 1939 r. AAN, Ambasada RP w Berlinie, 402, Pismo MSW do Ambasady RP w Berlinie, 3 IV 1939, k. 24.

${ }^{45}$ AAN, Ambasada RP w Berlinie, 398, Pismo naczelnika wydziału w MSW, W Żyborskiego, do ambasadora RP w Berlinie, J. Lipskiego, 7 IX 1935, k. 17.

${ }^{46}$ W 1935 r. przekazano 11 przesyłek; w 1936 r. - 18; w 1937 r. - 18; w 1938 r. - 28; w 1939 r. -16.

${ }^{47}$ AAN, Ambasada RP w Berlinie, 402, Pismo radcy w MSW, J. Schulza, do Ambasady RP w Berlinie, 13 VII 1939, k. 33.

${ }^{48}$ Brak pierwszych czterech stron dokumentu utrudnia jego analizę i datowanie. Jeśli wierzyć opisowi archiwalnemu jednostki akt, w której się znajduje, lista powstała w 1935 r. AAN, Ministerstwo Spraw Wewnętrznych (dalej: MSW), 1149 (mf 25722), „Spis i album działaczy komunistycznych, rejestrowanych przez gestapo", Departament Polityczny MSW, Wydział Bezpieczeństwa (1935), k. 60, 86.

${ }^{49}$ O tym, że lista zawierała nazwiska „komunistów niemieckich” pisał m.in. Andrzej Pepłoński, Policja państwowa, s. 157.

50 AAN, MSW, 1149 ( $m f$ 25722), „Spis i album działaczy komunistycznych, rejestrowanych przez gestapo", Departament Polityczny MSW, Wydział Bezpieczeństwa (1935), k. 87.

51 Ibidem, k. 90. 
centralnego komitetu KPP, którego określono jako „faktycznego przywódcę KPP", który został zamordowany w Moskwie w 1937 r. ${ }^{52}$

W spisie nie zabrakło czołowych dygnitarzy ZSRS, m.in. ludowego komisarza spraw zagranicznych Maksyma Litwinowa [Maksim Litvinov], określonego jako międzynarodowy komunistyczny agitator; Nikołaja Bucharina [Nikolaj Buharin], scharakteryzowanego jako bliski współpracownik Józefa Stalina; ludowego komisarza spraw wewnętrznych Gienricha Jagody [Genrih Âgoda] (według listy: szefa GPU) i Karola Radka, który na początku lat dwudziestych XX w. zaangażowany był w działania na odcinku niemieckim ${ }^{53}$. W spisie znaleźli się również szef Kominternu Georgi Dymitrow [Georgi Dimitrov] ${ }^{54}$ oraz przebywający od lat na emigracji Lew Trocki [Lev Trockij], a także przywódcy ruchu komunistycznego w innych państwach europejskich, m.in. Klement Gottwald, Bela Kun, Maurice Thorez i Palmiro Togliatti, a nawet filozof José Ortega y Gasset ${ }^{55}$. Nieznane są intencje, z jakimi lista została przekazana Polsce. Ewentualność zatrzymania przez władze polskie którejkolwiek osoby z listy i przekazania Niemcom można raczej wykluczyć.

Okazuje się, że nawiązane polsko-niemieckie kontakty władz bezpieczeństwa miały na tyle poufny charakter, że nie zdawała sobie sprawy z ich istnienia nawet część najwyższych urzędników polskiej dyplomacji. W styczniu 1936 r. wicedyrektor Departamentu Politycznego MSZ, Tadeusz Kobylański, pisał w instrukcji dla Ambasady RP w Berlinie:

Według informacji prasowych, na skutek włamania do Poselstwa Sowieckiego w Pradze, zostały ujawnione pewne szczegóły organizacji i działalności Kominternu w środkowej i wschodniej Europie. Podobno w związku z tym aresztowano w Niemczech 400 osób. [--] Ministerstwo Spraw Zagranicznych prosi, o ile poufne informacje Ambasady potwierdzają fakt aresztowań, o oficjalne sprawdzenie tych wiadomości i w danym razie omówienie ze stroną niemiecką nawiązania kontaktów informacyjnych między polskimi i niemieckimi władzami bezpieczeństwa ${ }^{56}$.

52 Ibidem, k. 47.

${ }^{53}$ Ibidem, k. 9, 36, 63, 87.

${ }^{54}$ Dymitrow, przebywający nielegalnie w Niemczech, został aresztowany w marcu 1933 r. po pożarze Reichstagu. Został oskarżony o podpalenie Reichstagu i zdradę stanu. Po uniewinnieniu przez Reichsgericht w Lipsku, został objęty aresztem ochronnym, a następnie został ekstradowany przez Niemcy do ZSRS 27 lutego $1934 \mathrm{r}$. The Diary of Georgi Dimitrov 1933-1949, oprac. I. Banac, New Haven-London 2003, s. 2, 7-8.

55 AAN, MSW, 1149 ( $\mathrm{mf}$ 25722), „Spis i album działaczy komunistycznych, rejestrowanych przez gestapo", Departament Polityczny MSW, Wydział Bezpieczeństwa (1935), k. 13, 25, 28, 44, 78, 79 .

${ }^{56}$ AAN, Ambasada RP w Berlinie, 399, Pismo wicedyrektora Departamentu Politycznego MSZ T. Kobylańskiego do Ambasady RP w Berlinie, 13 I 1936, k. 4. 
Kobylański nie zdawał sobie zatem sprawy, że takie kontakty zostały już nawiązane. Ambasador Lipski odpowiedział pismem oznaczonym klauzulą „ściśle tajne, do rąk własnych”, w którym wyjaśniał, że „od dłuższego czasu istnieją informacyjne kontakty między polskimi a niemieckimi władzami bezpieczeństwa. Bliższych szczegółów pod tym względem mógłby udzielić Panu Dyrektorowi P. Wiceminister Kawecki. Sądzę, że tą drogą uzyskałoby się najskuteczniej wiadomości, o których wspomina powyższe pismo Pana Dyrektora" 57 .

Kilka miesięcy później, w maju 1936 r., Ambasada Niemiec w Warszawie poinformowała polski MSZ,

jakoby w Łodzi znajdowała się grupa agentów sowieckich pod kierownictwem niejakiego Liutikowa. Powyższa grupa nawiązała rzekomo kontakt z komunistami niemieckimi, którzy w charakterze kupców przyjeżdżają z Niemiec do Łodzi przywożąc meldunki i otrzymując instrukcje. Ambasada [Niemiec] zaznaczyła, że właściwym władzom niemieckim zależałoby na otrzymaniu ewentualnych szczegółów o powyższej organizacji. Komunikując o powyższym, Ministerstwo Spraw Zagranicznych pozostawia uznaniu Ministerstwu Spraw Wewnętrznych bezpośrednie udzielenie informacji w tej sprawie kompetentnym władzom niemieckim w Berlinie, zaznaczając, że uważa za właściwe, aby informacje $w$ tego rodzaju sprawach były przedmiotem bezpośrednich kontaktów centralnych władz bezpieczeństwa obu państw ${ }^{58}$.

Wynika z tego, że również w Berlinie nie wszystkie zainteresowane urzędy były poinformowane o nawiązaniu bezpośrednich kontaktów między Gestapo a MSW i korespondencję w tej sprawie kierowano za pośrednictwem Ambasady Niemiec w Warszawie do polskiego MSZ. Na pismo dotyczące kontaktów między komunistami niemieckimi a agentami sowieckimi w Łodzi MSW odpowiedziało w sierpniu 1936 r., informując, że „w toku wszechstronnie przeprowadzonych wywiadów nie ujawniono na terenie Łodzi grupy agentów, którzy by utrzymywali kontakty z komunistami niemieckimi"59.

Nawiązanie w 1935 r. kontaktów między władzami bezpieczeństwa umożliwiło w kolejnym rozpoczęcie współpracy między szefostwem polskiej i niemieckiej policji mundurowej: PP i Orpo, której efektem były wizyty kurtuazyjne na najwyższym szczeblu oraz wymiana oficerów.

57 AAN, Ambasada RP w Berlinie, 399, Pismo ambasadora RP w Berlinie, J. Lipskiego, do wicedyrektora Departamentu Politycznego MSZ, T. Kobylańskiego, 24 I 1936, k. 5.

58 AAN, Ambasada RP w Berlinie, 399, Pismo wicedyrektora Departamentu Politycznego MSZ, J. Potockiego, do Departamentu Politycznego MSW, 30 V 1936, k. 12.

59 AAN, Ambasada RP w Berlinie, 399, Pismo naczelnika wydziału w MSW, W. Żyborskiego, do MSZ, 19 VIII 1936, odpis dla Ambasady RP w Berlinie, k. 35. 
Komendant główny PP Zamorski po raz pierwszy gościł w Niemczech od 17 do 22 maja 1936 r. na zaproszenie Daluege'a, szefa Orpo, bliskiego współpracownika Himmlera. W podróży do Berlina towarzyszyli mu: szef sztabu Komendy Głównej [KG] PP inspektor Juliusz Kozolubski, p.o. naczelnika Centrali Służby Śledczej nadkomisarz Józef Jakubiec i naczelnik Urzędu Śledczego m.st. Warszawy nadkomisarz Stanisław Wasilewski. Delegacji PP zaprezentowano nie tylko funkcjonowanie Orpo, ale również Sipo (zorganizowano m.in. spotkanie z korpusem oficerskim i wizytę w Instytucie Policyjnym w Berlinie-Charlottenburgu). Zamorski udzielił wywiadu organowi prasowemu NSDAP - „Völkischer Beobachter”, a krótką informację o przebiegu wizyty zamieścił fachowy dwutygodnik policyjny „Der deutsche Polizeibeamte"60. Pismo to przedrukowało również list Zamorskiego do szefa Orpo z 26 maja, w którym znalazło się podziękowanie za serdeczne przyjęcie w Berlinie i zaproszenie do Polski ${ }^{61}$.

W polskiej fachowej prasie policyjnej również znalazło się kilka tekstów dotyczących policji niemieckiej. „Przegląd Policyjny” opublikował artykuł o organizacji policji w III Rzeszy (w tym pozytywnie oceniający rolę Gestapo), którego autorem był Daluege ${ }^{62}$. Kilka miesięcy później zamieszczono kolejny tekst szefa Orpo, tym razem dotyczący zwalczania przestępczości w III Rzeszy ${ }^{63}$, w którym Daluege zachwalał „areszt ochronny" (osadzenie w obozie koncentracyjnym bez wyroku sądu, wyłącznie na mocy decyzji Gestapo) jako środek w zwalczaniu „wrogów społeczeństwa”. Z kolei w 1937 r. na łamach „Przeglądu Policyjnego” zreferowano treść radiowego przemówienia Himmlera z okazji święta niemieckiej policji, podkreślając rolę odgrywaną przez Reichsführera SS i szefa niemieckiej policji (od 1936 r. taki tytuł nosił Himmler), szefów Sipo i SD (Heydricha) oraz Orpo (Daluege). Zaznaczono, że właśnie „ "Gestapo» formalnie rozgromiła kadry komunistyczne i inne żywioły wywrotowe zagrażające bezpieczeństwu państwa i w zarodku

${ }^{60}$ Polnische Polizei besucht Berlin, „Der deutsche Polizeibeamte” 1 VI 1936, 11, s. 425; E.C. Król, op. cit., s. 149-150; M. Przegiętka, Podpułkownik żandarmerii Hans Köllner, jeden $z$ organizatorów Policji Polskiej tzw. granatowej w Generalnym Gubernatorstwie, w: Polnische Polizei im Generalgouvernement. Policja Polska ,granatowa” w Generalnym Gubernatorstwie w latach 1939-1945, red. T. Domański, E. Majcher-Ociesa, Warszawa-Kielce 2019.

61 „Der deutsche Polizeibeamte” 1 VII 1936, 13, s. 507.

${ }^{62}$ K. Daluege, Organizacja policji w narodowo-socjalistycznej Rzeszy Niemieckiej, „Przegląd Policyjny" 1936, 3, s. 170-176.

${ }^{63}$ K. Daluege, Zwalczanie przestępczości w Niemczech narodowo-socjalistycznych, „Przegląd Policyjny” 1937, 1, s. 26-31. Było to tłumaczenie fragmentu książki: K. Daluege, Nationalsozialistischer Kampf gegen das Verbrechertum, München 1936. 
z całą energią tłumiła wszelkie nawet próby rozwijania działalności przeciwpaństwowej" ${ }^{64}$.

Zaledwie miesiąc po wizycie Zamorskiego w Berlinie (maj 1936) nowa delegacja PP ponownie gościła w Niemczech. W dniach 15-19 czerwca 1936 r. w Berlinie przebywali nadkomisarz Józef Jakubiec, nadkomisarz Stanisław Wasilewski i komisarz Karol Penkała. Natomiast na zaproszenie Zamorskiego od 3 do 6 listopada tego roku gościł w Polsce Daluege. Towarzyszyło mu kilku oficerów, szef sztabu Adolf von Bomhard i referent prasowy w Głównym Urzędzie Orpo Helmuth Koschorke. Goście złożyli wieńce na Grobie Nieznanego Żołnierza w Warszawie oraz na sarkofagu Józefa Piłsudskiego na Wawelu. Daluege przywiózł „pozdrowienie od szefa policji niemieckiej Himmlera" i zapowiedź dalszego zacieśniania współpracy policji obu państw ${ }^{65}$. Niemiecką delegację podejmował w Warszawie nie tylko Zamorski, lecz również premier i minister spraw wewnętrznych Sławoj Składkowski i wiceminister Kawecki. Relację z wizyty szefa Orpo w Polsce opublikował Koschorke na łamach „Der deutsche Polizeibeamte”. Jej fragment dotyczy roli Kaweckiego w zwalczaniu ruchu komunistycznego:

Resortem [tj. MSW - M.P.] kieruje w praktyce wiceminister spraw wewnętrznych, sekretarz stanu Henryk Kawecki. Kawecki należy do grona trzydziestu najbliższych współpracowników zmarłego Marszałka. [--] Henryk Kawecki zna Niemcy osobiście i lubi prowadzić prywatne rozmowy. Krótka rozmowa z nim dowodzi wielkiego zainteresowania rozwojem narodowosocjalistycznych Niemiec. Jest on tym człowiekiem w Polsce, który pociąga za sznurki $\mathrm{w}$ walce $\mathrm{z}$ bolszewicką agitacją ${ }^{66}$.

Zacytowany fragment to jedyna oficjalna publikacja ukazująca rolę Kaweckiego w zwalczaniu ruchu komunistycznego, wskazująca również na jego kontakty z niemiecką policją w tej sprawie ${ }^{67}$.

${ }^{64}$ Zadania niemieckiej policji narodowo-socjalistycznej, „Przegląd Policyjny” 1937, 2, s. $148-149$.

${ }^{65}$ M. Przegiętka, op. cit., passim.

${ }^{66}$ „Das Ressort wird praktisch von Vize-Innenminister Staatssekretär Henryk Kawecki verwaltet. Kawecki gehört zu den dreißig engsten Mitarbeitern um den verstorbenen Marschall. [--] Henryk Kawecki kennt Deutschland persönlich und liebt die persönliche Aussprache von Mann zu Mann. Ein kurzes Gespräch mit ihm beweist sein reges Interesse für die Aufbauarbeit des nationalsozialistischen Deutschland. Es ist der Mann in Polen, in dessen Hand die Fäden des Kampfes gegen die bolschewistische Agitation zusammenlaufen”, H. K.[oschorke], Bei der Polizei in Polen, „Der deutsche Polizeibeamte" 15 XII 1936, 24, s. 942-943. Tłumaczenie fragmentów źródeł tu i dalej - M.P.

${ }^{67}$ Kawecki, w czasie okupacji przebywający w Warszawie, został jesienią 1939 r. aresztowany przez Gestapo. Według Władysława Żeleńskiego, opierającego się na relacji 
Wyrazem zapowiadanego zacieśnienia kontaktów policji mundurowych obu państw było zorganizowanie wymiany oficerów policji z inicjatywy szefa Orpo. Latem 1937 r. na trzymiesięczny staż wyjechało do Niemiec trzech oficerów PP (program przewidywał pobyt m.in. w Berlinie, Hamburgu i Kolonii), a w Polsce w tym samym czasie przebywało trzech oficerów Orpo (m.in. w Warszawie, w Szkole Szeregowych PP w Mostach Wielkich oraz w województwach białostockim, lwowskim, stanisławowskim i wileńskim). Niemal wszyscy komendanci PP, którzy przyjmowali niemieckich gości, zaobserwowali szczególne zainteresowanie oficerów Orpo problemem zwalczania ruchu komunistycznego. Jeden z niemieckich stażystów, mjr żandarmerii Hans Köllner, miał okazję wykorzystać zdobytą wiedzę o funkcjonowaniu PP w czasie okupacji. Od jesieni 1939 r. nadzorował tworzenie polskiej policji granatowej najpierw w Warszawie, a następnie, po przeniesieniu do sztabu dowódcy Orpo w Krakowie, w całym Generalnym Gubernatorstwie ${ }^{68}$.

Przed wybuchem wojny szef Orpo jeszcze raz gościł w Polsce. Daluege razem z płk. Schutzpolizei (Policji Ochronnej) Herbertem Beckerem, późniejszym dowódcą Orpo w Generalnym Gubernatorstwie (od października 1939 r. do sierpnia 1940 r. oraz od maja 1942 do lipca 1943 r.), przyjechał na polowanie trwające od 31 stycznia do 9 lutego 1938 r. Niemieccy goście razem z Zamorskim i ministrem spraw wojskowych gen. Tadeuszem Kasprzyckim spędzili kilka dni w Puszczy Białowieskiej, a następnie na Lubelszczyźnie (w Jabłoniu, gdzie podejmował ich August hr. Zamoyski). Obecny był ponadto attaché wojskowy Niemiec w Warszawie, płk Bogislav von Studnitz. Z kolei Zamorski gościł na Parteitagu we wrześniu 1938 r. Chociaż zaproszenie przyjął niechętnie, był pod wrażeniem wizyty w Niemczech ${ }^{69}$.

Mikołaja Dolanowskiego, pracownika MSW, zwolniono go, ponieważ znaleziono u niego „kordelas niemieckiej policji, z wyrytą dedykacją Himmlera”, W. Żeleński, Jeszcze o zabójstwie Pierackiego i rozrachunkach polsko-ukraińskich, „Zeszyty Historyczne” 1978, 46, s. 138. Według innej relacji Kawecki miał zostać aresztowany w lipcu 1940 r., L. Landau, Kronika lat wojny i okupacji, t. 1: Wrzesień 1939 - listopad 1940, do dr. przygot. Z. Landau, J. Tomaszewski, Warszawa 1962, s. 576. Kawecki zmarł w Warszawie 19 stycznia 1942 r. D. Mycielska, J.M. Zawadzki, Senatorowie zamordowani, zaginieni, zmarli w latach II wojny światowej, Warszawa 2009, s. 149.

${ }^{68}$ M. Przegiętka, op. cit., passim.

${ }^{69}$ Ibidem. 
Kontakty polskich i niemieckich władz bezpieczeństwa na tle kontaktów z władzami bezpieczeństwa innych państw

Podobnie bliskie kontakty PP utrzymywała jedynie z policją węgierską, której również poświęcano sporo uwagi w prasie fachowej oraz zorganizowano wymianę oficerów ${ }^{70}$. Ponieważ polsko-węgierskie kontakty policyjne także nawiązano na niwie zwalczania ruchu komunistycznego, nie od rzeczy będzie krótkie ich zaprezentowanie, tym bardziej że w dokumentach na ich temat odnajdujemy także wzmianki odnoszące się do kontaktów polsko-niemieckich.

Delegacja PP z komendantem głównym na czele odwiedziła Budapeszt we wrześniu 1936 r. Zamorskiemu towarzyszyli Kozolubski, Jakubiec, Wasilewski i oficer inspekcyjny w KGPP, inspektor Jan Płotnicki ${ }^{71}$, a zatem w znacznej części osoby, które uczestniczyły już w nawiązaniu kontaktów z policją niemiecką. W komunikacie przeznaczonym dla Poselstwa RP w Bukareszcie cel wyjazdu delegacji PP podsekretarz stanu w MSZ Jan Szembek określił następująco: „gen. Zamorski udaje się dziś do Budapesztu celem nawiązania kontaktu z Komendą policji węgierskiej w sprawach zwalczania komunizmu. Wizyta ta nosi wyłącznie charakter fachowy [tzn. niepolityczny - M.P.]"72. Od 8 do 15 listopada tego samego roku w Polsce gościła delegacja węgierska, której przewodzili komendant główny policji Tibor Ferenczy oraz radca Ministerstwa Spraw Wewnętrznych Dénes Szemerjay-Kovács. Zostali oni przyjęci przez Zamorskiego oraz Kaweckiego, który - jak informował „Przegląd Policyjny” - „zwrócił uwagę na doniosłość zacieśniającej się współpracy służb bezpieczeństwa obu państw"73. O ustaleniach będących wynikiem tej wizyty raportował do Budapesztu poseł węgierski, informując przy okazji również o polsko-niemieckich kontaktach w tej dziedzinie:

Praktycznym rezultatem wizyty jest nawiązanie gentlemen's agreement między policją węgierską i polską w celu wspólnej obrony przed komunizmem.

${ }^{70}$ W 1938 r. zorganizowano trzymiesięczny staż dla trzech oficerów węgierskiej policji. AAN, Komenda Główna Policji Państwowej w Warszawie (dalej: KGPP), 2204, Okólnik KGPP, 3 VI 1938, k. 15.

${ }^{71}$ AAN, Ministerstwo Spraw Zagranicznych, 6616 (mf B 22893), Pismo MSW do MSZ, 17 VIII 1936, k. 3; R. Litwiński, Kordian Józef Zamorski, s. 195.

72 AAN, Ministerstwo Spraw Zagranicznych, 6616 ( $m f$ B 22893), Odpis telegramu podsekretarza stanu w MSZ J. Szembeka dla Poselstwa RP w Bukareszcie, 22 IX 1936, k. 5v.

73 Odwiedziny przedstawicieli wegierskiej policji i żandarmerii w Polsce, „Przegląd Policyjny" 1937,1 , s. 62-65. 
Polacy już dużo wcześniej porozumieli się w tej sprawie z Niemcami [wyróżnienie - M.P.], jednak nasz układ idzie dużo dalej od tamtego. Delegacja przedstawi tekst ustaleń ministrowi spraw wewnętrznych do zaakceptowania, a ten o ich treści poinformuje bezpośrednio Waszą ekscelencję. [--] Według mojego odczucia, niezależnie od faktycznych wyników pozytywnym skutkiem wizyty było to, że wysocy urzędnicy [polscy - M.P.] wielokrotnie powtarzali, iż lepiej porozumieli się z Węgrami niż z Niemcami, z którymi nie doszło do takiego zbliżenia ${ }^{74}$.

Notatka powyższa stanowi nie tylko potwierdzenie istnienia kontaktów między polskimi a niemieckimi władzami bezpieczeństwa. Jest również wskazówką dotyczącą formy porozumienia polsko-niemieckiego. Jeśli przybrało ono rzeczywiście postać gentlemen's agreement ${ }^{75}$, jak porozumienie polsko-węgierskie, nic dziwnego, że poszukiwania dokumentu zawierającego tekst porozumienia nie przyniosły rezultatu.

Jak już sygnalizowano, nie jest znana treść polsko-niemieckiego porozumienia. Wiadomo jednak, jakie postanowienia były pożądane z punktu widzenia szefa Sipo i SD Heydricha przy zawieraniu umów policyjnych. W grudniu 1936 r. w piśmie do Urzędu Spraw Zagranicznych, opierając się na obowiązujących już porozumieniach tego typu (a więc i umowie z Polską) wymienił on najważniejsze zapisy, jakie powinny się w tego typu umowach znaleźć: wymiana doświadczeń i informacji oraz wzajemne wspieranie się $\mathrm{w}$ dochodzeniach dotyczących działalności komunistycznej i anarchistycznej ${ }^{76}$. 0 tym, że taką współpracę nawiązano z wieloma państwami europejskimi i pozaeuropejskimi, świadczy lista państw reprezentowanych na konferencji policyjnej poświęconej zwalczaniu działalności komunistycznej, zorganizowanej przez Heydricha latem 1938 r. w Berlinie. Wzięli w niej udział przedstawiciele Argentyny,

${ }^{74}$ Raport posła Królestwa Węgier, Andrása Horyego, dla ministra spraw zagranicznych Królestwa Węgier, Kálmána Kányi, na temat wizyty komitetu węgierskich sił porządkowych w Warszawie, 17 XI 1936 r., w: A. Hory, „Martwa placówka”. Wspomnienia i korespondencja posła Królestwa Węgier w Warszawie 1935-1939, Warszawa 2017, s. 201-202, dok. 22.

75 Według Juliana Makowskiego „Gentlemen agreement (czasami gentleman's self denial) jest zobowiązaniem nie prawnym, lecz moralnym, opartym na dobrej woli współkontrahenta. W razie niedotrzymania obietnicy, strona poszkodowana nie może stosować takich sankcji, jakie są dopuszczalne w razie zerwania traktatu (represalje [sic], sąd rozjemczy itp.)", J. Makowski, Prawo międzynarodowe, cz. 1, Warszawa 1930, s. 322). Ponadto: „Pełnomocnik, który je zaciągnął, obowiązany jest osobiście wykonać je; nie wiąże ono jednak państwa”, idem, Podręcznik prawa międzynarodowego, Warszawa 1948, s. 441.

${ }^{76}$ Brasilianische und deutsche Polizei sollen gemeinsame Sache machen, 23 XII 1936 r., w: Misstrauische Nachbarn. Deutsche Ostpolitik 1919/1970. Dokumentation und Analyse, oprac. H.-A. Jacobsen, współpraca W. Bredow, Düsseldorf 1970, dok. 26, s. 106-107. 
Belgii, Bułgarii, Finlandii, Grecji, Japonii, Jugosławii, Polski, Portugalii, Węgier, Włoch oraz Wolnego Miasta Gdańska. Zgodnie z poleceniem Składkowskiego Polskę reprezentować miał następca Kaweckiego na stanowisku dyrektora Departamentu Politycznego MSW, Wacław Żyborski, jednak ostatecznie w zastępstwie do Niemiec pojechał dyrektor Departamentu Bezpieczeństwa MSW, Jerzy Krzymowski, a wraz z nim Stefan Szymborski, zastępca kierownika referatu informacyjnego w tym departamencie ${ }^{77}$.

Sprawa współdziałania w zwalczaniu komunizmu stała się przedmiotem rozmowy ministra spraw zagranicznych von Ribbentropa i ambasadora Lipskiego 31 marca 1938 r. Ribbentrop pozytywnie ocenił dotychczasową polsko-niemiecką współpracę i umowę policyjną oraz złożył propozycję dalszego zacieśnienia kontaktów przez przystąpienie do paktu antykominternowskiego:

Następnie wyjaśniłem panu Lipskiemu, że Niemcy z uznaniem oceniają działania Polski przeciwko komunizmowi, a przede wszystkim polsko-niemiecką współpracę na tym polu, która znalazła odzwierciedlenie w umowie policyjnej. Jak wiadomo, Niemcy z Włochami i Japonią zjednoczyły się we wspólnej obronie przed komunizmem. Nasza współpraca z tymi państwami sprawdziła się. Cieszyłbym się, gdyby Niemcy i Polska, jak to zostało zapoczątkowane dzięki umowie policyjnej, dalej poświęcały dużą uwagę problemowi komunizmu i jeszcze ściślej współpracowały w obronie przed nim ${ }^{78}$.

Konfrontacja dokumentu Ribbentropa z raportem polskiego ambasadora pozwala na poczynienie interesujących spostrzeżeń. Lipski - inaczej niż Ribbentrop - nie mówił o „umowie policyjnej”, lecz o „poufnym porozumieniu w tym względzie z władzami bezpieczeństwa niemieckiego,

77 M. Majewski, Jerzy Krzymowski - ostatni naczelnik Wydziału Bezpieczeństwa MSW (1937-1939), w: Sekretna Wojna II. Z dziejów kontrwywiadu II RP (1914) 1918-1945 (1948), red. Z. Nawrocki, Poznań 2015, s. 552-553.

78 „Ich erklärte Herrn Lipski weiter, daß Deutschland die Abwehrarbeit Polens gegen den Kommunismus begrüße, und vor allem die deutsch-polnische Zusammenarbeit auf diesem Gebiet, die in dem Polizei-Abkommen ihren Niederschlag gefunden habe. Es sei ihm ja bekannt, daß Deutschland mit Italien und Japan durch den Anti-KominternVertrag in gemeinsamer Abwehr gegen den Kommunismus vereinigt seien. Unsere Zusammenarbeit mit diesen Staaten habe sich durchaus bewährt. Ich würde mich freuen, wenn Deutschland und Polen, wie das durch das Polizei-Abkommen ja schon eingeleitet worden sei, dem Problem des Kommunismus weiter volle Aufmerksamkeit schenken und in der Abwehr immer enger zusammen arbeiten würden", Aufzeichnung des Reichsaußenministers, Berlin, 31 III 1938 r., w: Akten zur deutschen auswärtigen Politik, seria D, t. 5: Polen, Südosteuropa, Lateinamerika, Klein- und Mittelstaaten, Juni 1937 - März 1939, Baden-Baden 1953, dok. 34, s. 39. 
które dobrze funkcjonuje"79. Ambasador, wspominając o zwalczaniu komunizmu w Polsce i odpowiadając na zaproszenie do paktu antykominternowskiego, dodał: „w praktyce na wszystkich odcinkach zwalczamy, podobnie jak Niemcy, akcję kominternu. Niemniej, jeśli chodzi o zewnętrzne manifestacje, to musimy liczyć się z naszą specjalną sytuacją jako bezpośredni sąsiedzi Rosji Sowieckiej, tym bardziej że mamy obliga wynikające ponadto z naszego aliansu z Rumunią"80.

Wypowiedź ambasadora Lipskiego oddaje stanowisko rządu polskiego w sprawie zaproszenia do paktu antykominternowskiego. Minister Beck w instrukcji z 9 listopada 1937 r. dla ambasady RP w Berlinie stwierdził, że Polska nie może przystąpić do paktu „ze względu na swoje specyficzne położenie jako sąsiad ZSRR oraz na zasadnicze stanowisko przeciwne blokom” Biuletynie Informacyjnym" Polskiej Informacji Politycznej, który został jednak poszerzony o zdanie: „Negatywne stanowisko do przystąpienia do paktu nie oznacza bynajmniej rezygnacji z walki z wpływami Kominternu na wewnątrz Polski, która jak była, tak i będzie nadal prowadzona we własnym zakresie z całą stanowczością"82.

W podpisanym 25 listopada 1936 r. pakcie antykominternowskim Niemcy i Japonia uznawały zgodnie, że celem działalności Kominternu jest „rozkład i owładnięcie istniejącymi państwami przy pomocy wszelkich będących do rozporządzenia środków" i deklarowały współpracę w jego zwalczaniu, przez co rozumiano wymianę informacji o działalności organizacji, konsultacje co do „środków obrony” i „ścisłe współdziałanie przy wprowadzaniu ich w życie”. Pakt miał być otwarty na państwa trzecie, które „będą zaproszone [--] do poczynienia zarządzeń obronnych w duchu niniejszego Układu lub do wzięcia w nim udziału". Postanowienia te precyzował protokół dodatkowy, w którym była mowa o tym, że wzajemne informowanie o działalności Kominternu oraz $\mathrm{w}$ podejmowanej „akcji uświadamiającej i obronnej” zostanie powierzone „władzom kompetentnym” obu państw, które w tym celu utworzą „Stałą Komisję” oraz „podejmą, w ramach obowiązujących ustaw, surowe zarządzenia przeciwko tym, którzy bądź w kraju, bądź za granicą, bezpośrednio lub

79 List ambasadora $w$ Berlinie o rozmowie z ministrem spraw zagranicznych Niemiec, 31 III 1938 r., w: Polskie dokumenty dyplomatyczne. 1938, red. M. Kornat, współpraca P. Długołęcki, M. Konopka-Wichrowska, M. Przyłuska, Warszawa 2007, dok. 74, s. 181.

${ }^{80}$ Ibidem.

${ }^{81}$ Telegram ministra spraw zagranicznych do ambasady $w$ Berlinie na temat stosunku Polski do paktu antykominternowskiego, 9 XI 1937 r., w: Polskie dokumenty dyplomatyczne. 1937, red. J.S. Ciechanowski, współpraca P. Długołęcki, Warszawa 2012, dok. 261, s. 674.

${ }^{82}$ Tygodniowy Biuletyn Informacyjny Polskiej Informacji Politycznej (fragment): stosunek Polski do paktu antykominternowskiego, 12 XI 1937 r., w: ibidem, dok. 262, s. 675. 
pośrednio pozostają na usługach Międzynarodówki Komunistycznej lub pomagają w jej robocie rozkładowej"83. Wkrótce po zawarciu przez Niemcy i Japonię paktu antykominternowskiego rozpoczęły się bezowocne próby niemieckiej dyplomacji nakłonienia Polski do przystąpienia do tego porozumienia ${ }^{84}$. Jedną z takich prób podjął 11 stycznia $1938 \mathrm{r}$. Ribbentrop w rozmowie z Beckiem. Polski minister, mówiąc o stosunkach z ZSRS, podkreślił negatywne nastawienie rządu polskiego wobec komunizmu oraz wspomniał o ostrym przeciwdziałaniu komunistycznej propagandzie w Polsce. Jak zanotował radca legacyjny Martin Schliep (z Wydziału Politycznego niemieckiego MSZ), Warszawa „w żaden sposób nie zamierza przystąpić do paktu antykominternowskiego" ${ }^{85}$. Polska prezentowała konsekwentnie takie stanowisko do wybuchu wojny.

\section{Korespondencja Henryka Kaweckiego}

Do dziś zachowała się tylko część korespondencji, jaką wymieniały MSW i Gestapo. Odgrywający szczególną rolę w polsko-niemieckich kontaktach policyjnych Henryk Kawecki, już po odejściu z MSW skierował do kogoś z niemieckich władz bezpieczeństwa list noszący datę 21 marca 1938 r.: „Wielce Szanowny Panie! Pozwalam sobie zwrócić się z uprzejmą prośbą o powiadomienie, czy i jaka specjalna ustawa antykomunistyczna obowiązuje na terenie Państwa Niemieckiego. Byłbym mocno wdzięczny za nadesłanie mi egzemplarza tej ustawy, o ile została wydana i opublikowana drukiem. Wyrażając gotowość wzajemnych usług pozostaję z należnym szacunkiem, Henryk" ${ }^{86}$. Jeszcze 21 marca list wraz z pismem przewodnim MSW z klauzula „,poufne” został wysłany przez Ministerstwo do Ambasady RP w Berlinie, której urzędnik otrzymał go do doręczenia 29 marca i tego samego dnia przekazał adresatowi ${ }^{87}$.

83 Układ między Niemcami a Japonia o zwalczaniu Kominternu (tzw. Pakt Antykominternowski), z dodatkowym protokółem, Berlin, 25 XI 1936 r., w: Dokumenty z dziejów polskiej polityki zagranicznej 1918-1939, t. 2: 1933-1939, red. T. Jędruszczak, M. Nowak-Kiełbikowa, Warszawa 1996, aneksy, dok. 4, s. 300-301.

${ }^{84}$ M. Broszat, 200 lat niemieckiej polityki wobec Polski, Warszawa 1999, s. 286-287; W. Michalka, Ribbentrop und die deutsche Weltpolitik 1933-1940. Außenpolitische Konzeptionen und Entscheidungsprozesse im Dritten Reich, München 1980, s. 271-273.

85 Aufzeichnung des Vortragenden Legationsrats Schliep (Pol. Abt.), Berlin, 11 I 1938 r., w: Akten zur deutschen auswärtigen Politik, dok. 25, s. 28.

${ }^{86}$ Bundesarchiv Berlin-Lichterfelde (dalej: BAB), Reichssicherheitshauptamt (dalej: RSHA), R 58/605, List (mps) z 21 III 1938 r., k. 13.

87 AAN, Ambasada RP w Berlinie 1920-1939, 401, Pismo naczelnika wydziału w MSW, J. Krzymowskiego, do ambasadora RP w Berlinie, J. Lipskiego, 21 III 1938, k. 5. 
Była to przyjęta w kontaktach między MSW a niemieckimi władzami bezpieczeństwa droga przesyłania korespondencji ${ }^{88}$. List został podpisany tylko imieniem. Przypuszczenie, że jego autorem był Kawecki, uprawdopodobnia fakt, iż w największym stopniu zaangażowany był w kontakty z niemieckimi władzami bezpieczeństwa, a poza tym od lat zajmował się obserwacją KPP ${ }^{89}$.

Nie wiadomo, kto konkretnie był adresatem listu. Nie ulega jednak wątpliwości, że był to wysoki funkcjonariusz Gestapo zajmujący się zwalczaniem komunizmu. Notatka na temat listu z 21 marca 1938 r. została przygotowana 8 lipca przez funkcjonariusza referatu II A 4 („Merytoryczna analiza wszystkich przejawów komunizmu na świecie” - „Sachliche Auswertung aller Erscheinungsformen des Kommunismus in der Welt"). Szefem całego wydziału II A (Sprawy wewnętrzne - Innenpolitischen Angelegenheiten) był Heinrich Müller (późniejszy szef Urzędu IV Gestapo w Głównym Urzędzie Bezpieczeństwa Rzeszy, RSHA) ${ }^{90}$. W notatce stwierdzono, że nie ma obiekcji przeciwko przekazaniu „zaufanemu urzędowi w Polsce” (,vertrauliche Stelle in Polen”) informacji o ustawach antykomunistycznych, które zostały następnie wymienione: 1) Rozporządzenie prezydenta Rzeszy o ochronie narodu i państwa z 28 lutego 1933 r. ${ }^{91}$; 2) Ustawa o konfiskacie mienia komunistycznego z 26 maja 1935 r.; 3) Ustawa o przeciwdziałaniu politycznym aktom przemocy z 4 kwietnia 1933 r.; 4) Ustawa o wymierzaniu kary śmierci z 29 lutego 1933 r.; 5) Ustawa o zagwarantowaniu spokoju prawnego z 19 października $1933 r^{92}$

Notatka została przekazana do referatu II J, odpowiadającego za kontakty międzynarodowe (Policje zagraniczne, kontakty z władzami zagranicznymi - Ausländische Polizeien, Verkehr mit Ausländischen Behörden ${ }^{93}$ ), który w oparciu o nią przygotował projekt odpowiedzi.

88 B. Gadomski, op. cit., s. 192.

89 G. Zackiewicz, Polska myśl polityczna wobec systemu radzieckiego 1918-1939, Kraków 2004, s. 467, przyp. 283.

90 J. Bornschein, op. cit., s. 29-31; A. Seeger, op. cit., s. 259-262.

91 To bez wątpienia jeden z najistotniejszych aktów prawnych III Rzeszy. Rozporządzenie podpisane nazajutrz po pożarze Reichstagu przez prezydenta Rzeszy Paula von Hindenburga na wniosek Hitlera zawieszało szereg praw obywatelskich pod pretekstem przeciwdziałania zagrożeniu komunistycznemu. Wprowadzało stan wyjątkowy, a wraz z nim instytucję aresztu ochronnego (Schutzhaft), który nie był uzależniony od wyroku sądu i od którego nie można było się odwołać. Był on podstawowym instrumentem represji w III Rzeszy. F. Ryszka, Państwo stanu wyjątkowego. Rzecz o systemie państwa i prawa Trzeciej Rzeszy, Wrocław-Warszawa-Kraków 1985, s. 203; C. Schmitz-Berning, Vokabular des Nationalsozialismus, Berlin-New York 1998, s. 568.

92 BAB, RSHA, R 58/605, Notatka, 8 VII 1938, k. 14.

93 BAB, RSHA, R 58/840, „Geschäftsverteilungsplan des Geheimes Staatspolizeiamtes vom 1. Januar 1938", k. 153-163. 
Nie wiemy jednak, czy odpowiedź została rzeczywiście wysłana do Warszawy ${ }^{94}$, ani tym bardziej, czy przesłane informacje zostały w jakikolwiek sposób wykorzystane. W przygotowanym projekcie odpowiedzi wymieniono podstawowe akty prawne, które przewidywały kary za działalność komunistyczną. W przedostatnim akapicie projektu odpowiedzi znalazło się zdanie, które jednak później zostało wykreślone: „Byłbym wdzięczny za powiadomienie, czy ustawy obowiązujące w Rzeszy Niemieckiej, zostały przyjęte jako podstawa podczas przygotowywania tamtejszych projektów ustaw w sprawie zwalczania działalności komunistycznej" ${ }^{95}$.

Inicjatywa Kaweckiego jest trudna do wyjaśnienia. Czy miała związek z przygotowaniem rozporządzenia Prezydenta RP z 22 listopada 1938 r. o ochronie interesów Państwa? ${ }^{96}$ Wprawdzie mogła mieć ona pewne znaczenie dla zwalczania ruchu komunistycznego (ale również innej działalności antypaństwowej czy skierowanej przeciwko Polsce działalności państw obcych i organizacji międzynarodowych), ale została przyjęta już po rozwiązaniu KPP przez Komintern ${ }^{97}$. Jak pisze Karol Sacewicz, „w międzywojennej Polsce nie udało się wypracować społeczno-politycznego konsensusu umożliwiającego przyjęcie antykomunistycznej ustawy"98, natomiast penalizację działalności antypaństwowej przewidywały obowiązujące już wcześniej przepisy, m.in. Kodeks karny z 1932 r. ${ }^{99}$

List z 21 marca 1938 r. nie jest jedynym śladem korespondencji Kaweckiego z Gestapo. Zachowały się ponadto tłumaczenia na niemiecki dwóch listów napisanych w Warszawie, noszących daty 7 i 30 listopada 1938 r., podpisanych tym samym imieniem, których autorem zapewne jest również Kawecki. Dotyczą one zmian w środkowoeuropejskich strukturach

${ }^{94} \mathrm{~W}$ aktach MSW przechowywanych w AAN nie natrafiono na korespondencje w tej sprawie.

95 „Ich wäre dankbar, wenn mir mitgeteilt werden könnte, ob die von dem Deutschen Reich erlassenen Gesetze als Grundlage für dortige Gesetzesentwürfe zur Bekämpfung der kommunistischen Tätigkeit verwendet werden", BAB, RSHA, R 58/605, Projekt odpowiedzi z 18 VII 1938 r., k. 15-15v.

${ }^{96}$ K. Sacewicz, Komunizm i antykomunizm w II Rzeczypospolitej. Państwo - społeczeństwo - partie, Olsztyn 2016, s. 129.

$97 \mathrm{Na}$ początku 1938 r. Komintern podjął decyzję o rozwiązaniu KPP. W uzasadnieniu stwierdzono, że została ona opanowana przez „agentów policji i prowokatorów”. Brak niestety nowszej literatury na ten temat, pozbawionej ideologicznych naleciałości. H. Cimek, L. Kieszczyński, Komunistyczna Partia Polski 1918-1938, Warszawa 1984, s. 439; J. Kowalski, Komunistyczna Partia Polski 1935-1938. Studium historyczne, Warszawa 1975, s. 426-427.

${ }^{98}$ K. Sacewicz, Komunizm i antykomunizm, s. 129.

99 K. Sacewicz, Centralna prasa Polski podziemnej wobec komunistów polskich 1939-1945, Warszawa 2009, s. 30. 
Kominternu, które były wynikiem porozumienia monachijskiego i rozbioru Czechosłowacji. Treść listu z 7 listopada:

Informuję posłusznie, że otrzymałem ostatnio informację o tym, że środkowoeuropejskie biuro Kominternu, które miało siedzibę w Pradze, od połowy roku stopniowo przenoszone jest do Paryża. Nie wiem, jak bardzo zaawansowany jest proces likwidacji biura w Pradze. Liczę się jednak z możliwością, że wskutek położenia, w jakim znajduje się Czechosłowacja, proces został przyspieszony. Byłbym zobowiązany za przekazanie mi informacji w tej sprawie. Z mojej strony nie omieszkam przekazać kolejnych wiadomości, gdy tylko je otrzymam ${ }^{100}$.

Jak wynika z adnotacji, list ten wpłynął do Gestapo „od polskiej policji" 17 listopada 1938 r., a przetłumaczono go 22 listopada. Tłumaczenie przekazano z datą 25 listopada do referatu II A 4 (tam, gdzie trafiała poprzednia korespondencja) oraz do wiadomości wydziału II A, którego szefem był Müller ${ }^{101}$. Kolejny list, z 30 listopada, dotyczył tej samej sprawy:

W nawiązaniu do mojego listu z 7 listopada br. uprzejmie informuję, że uzyskałem informacje, zgodnie z którymi duża część dotychczasowego personelu biura Kominternu w Pradze została już przeniesiona do Paryża. Odpowiedzialne osobistości Kominternu przypuszczalnie postanowiły nie rozwiązywać całkowicie biura na Europę Centralną, lecz jedynie ograniczyć

100 „Ich teile ergebenst mit, daß ich letztens Nachricht darüber erhalten habe, daß das Mitteleuropäische Komintern-Büro, das seinen Sitz in Prag hat, seit Mitte des Jahres nach und nach nach Paris verlegt wurde. Wie weit der Prozess der Auflösung des Büros in Prag vorgeschritten ist, ist mir nicht bekannt. Ich rechne jedoch mit der Möglichkeit, daß infolge der in der Tschecho-Slowakei eingetretenen Lage dieser Prozess beschleunigt worden ist. Ich wäre Ihnen für die Übermittlung etwaiger Nachrichten in dieser Angelegenheit sehr verbunden. Meinerseits werde ich nicht verfehlen weitere Nachrichten mitzuteilen, sowie ich solche erhalte", Rossijskij gosudarstvennyj arhiv socialno-političeskoj istorii (dalej: RGASPI), f. 458, op. 9, d. 125, 1.6, Tłumaczenie z polskiego na niemiecki listu H. Kaweckiego z 7 listopada 1938 r., http://rgaspi-458-9.germandocsinrussia.org/de/nodes/127-akte-nr-125-dokumente-des-gestapa-berlin-komintern-organis-beih-meb-organisationsstruktur-des-mitteleurop-ischen-b-ros-in-pragberichte-der-gestapo-zum-transport-des-archivs-des-b-ros-aus-prag-nach-moskau-berdie-versetzung-von-mitarbeitern-de\#page/6/mode/grid/zoom/1 (dostęp: 18 I 2019).

101 RGASPI, f. 458, op. 9, d. 125, 1. 5v., Adnotacja funkcjonariusza Gestapo, 16 XII 1938, http://rgaspi-458-9.germandocsinrussia.org/de/nodes/127-akte-nr-125-dokumente-des-gestapa-berlin-komintern-organis-beih-meb-organisationsstruktur-des-mitteleurop-ischen-b-ros-in-prag-berichte-der-gestapo-zum-transport-des-archivs-des-b-ros-aus-prag-nach-moskau-ber-die-versetzung-von-mitarbeitern-de\#page/6/ mode/grid/zoom/1 (dostęp: 18 I 2019). 
jego działalność przez przeorganizowanie w aparat pomocniczy paryskiego biura Kominternu. W tej formie powinno ono rozwijać swoją działalność w Europie Centralnej i w krajach bałkańskich. Równocześnie postanowiono zmienić jego skład personalny poprzez usunięcie współpracowników znanych policjom zainteresowanych państw. Zostali oni zastąpieni przez członków skandynawskiego aparatu Kominternu, który w mniejszym stopniu jest znany policji. Będę Panu bardzo wdzięczny, jeśli będzie Pan tak uprzejmy i przekaże mi informacje, jakimi dysponuje na ten temat ${ }^{102}$.

Zgodnie z adnotacją funkcjonariusza Gestapo na odwrocie tłumaczenia, list otrzymano „od polskiej policji” 8 grudnia 1938 r., a pięć dni później dokonano przekładu na niemiecki. Tłumaczenie przekazano do referatu II A 4 oraz do wiadomości wydziału II A.

W referacie II A 4 (I) 12 grudnia polecono przygotować odpowiedź na list z 7 listopada, w której dano do zrozumienia, że Gestapo wiedziało o przeniesieniu komórek Komunistycznej Partii Niemiec z Pragi do Paryża już w 1936 r., a komórek Komunistycznej Partii Austrii jesienią 1938 r. W dalszej części projektu odpowiedzi wyrażono przypuszczenie, że w związku ze zmianą położenia politycznego Czechosłowacji również zagraniczne kierownictwa partii komunistycznych Polski, Węgier i Jugosławii musiały zostać przeniesione, wobec czego nie jest wykluczone, że „biuro środkowoeuropejskie” mogło zostać przeniesione do Paryża.

Oficjalne kontakty polskich i niemieckich władz bezpieczeństwa zamyka przyjazd Himmlera do Warszawy (luty 1939). Według ambasadora

102 „Im Nachgange zu meinem Schreiben vom 7.11. ds.Jhrs. teile ich höflichst mit, dass ich Informationen erlangt habe, denen zufolge ein grosser Teil des bisherigen Personals des Prager Komintern-Büros bereits nach Paris versetzt worden ist. Die verantwortlichen Persönlichkeiten der Komintern haben angeblich beschlossen, das Büro für Zentral-Europa nicht vollkommen aufzulösen, sondern lediglich seine Tätigkeit durch Umgestaltung in einen Hilfsapparat des Pariser Komintern-Büros einzuengen. In dieser Form soll es seine Tätigkeit in Zentral-Europa sowie in den Balkanländern entfalten. Gleichzeitig hat man sich entschlossen, seinen Personalbestand durch Entfernung von der Polizei interessierten Länder bekannten Mitarbeitern zu verändern. Sie sollen durch Angehörige des skandinavischen Komintern-Apparates, welcher der Polizei weniger bekannt ist, ersetzt werden. Ich werde Ihnen sehr dankbar sein, wenn Sie so freundlich wären, mir wie in dieser Angelegenheit in Ihrem Besitz befindlichen Informationen mitzuteilen", RGASPI, f. 458, op. 9, d. 125, 1. 5, Tłumaczenie z polskiego na niemiecki listu H. Kaweckiego z 30 listopada 1938 r., http://rgaspi458-9.germandocsinrussia.org/de/nodes/127-akte-nr-125-dokumente-des-gestapaberlin-komintern-organis-beih-meb-organisationsstruktur-des-mitteleurop-ischenb-ros-in-prag-berichte-der-gestapo-zum-transport-des-archivs-des-b-ros-aus-pragnach-moskau-ber-die-versetzung-von-mitarbeitern-de\#page $/ 6 / \mathrm{mode} / \mathrm{grid} / \mathrm{zoom} / 1$ (dostęp: 18 I 2019). 
Lipskiego zaproszenie wystosował gen. Zamorski ${ }^{103}$. Natomiast komendant główny PP w swoim dzienniku dowodził, że wizyta została mu narzucona przez MSZ ${ }^{104}$. Zdaniem Szembeka Zamorski uważał przyjazd Himmlera do Polski „za bardzo potrzebny”"105, mimo że według MSW istniało niebezpieczeństwo demonstracji antyniemieckich. Przeciwny wizycie był dyrektor Departamentu Politycznego MSW, Żyborski, który ostrzegał, że „robota antypolska u nas, na Słowacczyźnie i Rusi prowadzona jest i finansowana przez Gestapo, które podlega bezpośrednio Himmlerowi. Wizyta Himmlera ułatwiłaby więc tylko wywiad niemiecki u nas" ${ }^{106}$.

Wizyta odbyła się w sytuacji, gdy stosunki polsko-niemieckie pogarszały się. Warszawa nie przyjęła złożonej przez Niemcy 24 października 1938 r. oferty całościowego uregulowania wzajemnych relacji (w tym przystąpienia przez Polskę do paktu antykominternowskiego), której akceptacja równałaby się utracie niezależności. To bez wątpienia wpływało na przebieg wizyty Himmlera, któremu towarzyszył jego adiutant, SS-Obergruppenführer Ludolf von Alvensleben. 18 lutego Reichsführer SS spotkał się nie tylko z Zamorskim (komendantowi głównemu towarzyszyli Adam Winnicki, który odbył staż w Niemczech w 1937 r., oraz nadkomisarz Wasilewski, który w Niemczech był dwukrotnie w 1936 r.) ${ }^{107}$, ale i Eugeniuszem Kwiatkowskim (który zastępował chorego premiera Składkowskiego) i ministrem spraw zagranicznych Beckiem, zapewniając ich o woli Hitlera utrzymania poprawnych stosunków z Polską. Tematy polityczne zdominowały rozmowę z Beckiem - oprócz kwestii polityki ZSRS i zagadnienia emigracji Żydów z Polski omawiano m.in. sprawę Ukrainy Zakarpackiej, Wolnego Miasta Gdańska i reformy rolnej w Polsce, która według Himmlera godziła w interesy Niemców ${ }^{108}$.

103 „Gen. Zamorski zaprosił ze swej strony Himmlera, co ambasador uważa za bardzo wskazane, gdyż osoba Himmlera coraz bardziej nabiera znaczenia”, Diariusz i teki Jana Szembeka (1935-1945), t. 4, oprac. J. Zarański, London 1972, s. 360 (zapis z 22 XI 1938).

$104 \mathrm{Na}$ to wskazuje z kolei inny zapis z Diariusza Szembeka: „[Lipski] wskazywał na konieczność i usilnie domagał się zaproszenia Himmlera. Szczegóły tej wizyty omówi z gen. Zamorskim". Nacisk na zaproszenie Himmlera wynikać musiał również z odmowy Göringa przyjazdu na polowanie do Polski, ibidem, s. 481 (zapis z 27 I 1939).

105 Ibidem, s. 401 (zapis z 21 XII 1938).

106 Ibidem.

107 AAN, KGPP, 2204, „Wykaz gości niemieckich zamieszkałych w Hotelu Europejskim”, luty 1939, k. 2; ibidem, „Lista obecnych na śniadaniu dn. 18 II [1939] w Hotelu Europejskim", k. 5-6; ibidem, Okólnik komendanta głównego PP: program wizyty Himmlera w Polsce, 16 II 1939, k. 7.

108 Wizyta szefa policji niemieckiej Himmlera w Polsce, „Przegląd Policyjny” 1939, 2, s. 147-148; E.C. Król, op. cit., s. 203; B. Wiaderny, op. cit., s. 104-105; S. Żerko, Stosunki polsko-niemieckie..., s. 152, 223, 227-230. 
Z wizyty Himmlera zachowała się notatka Mirosława Arciszewskiego, zastępcy podsekretarza stanu w MSZ. Reichsführer SS deklarował m.in., że „załatwienie sprawy gdańskiej [w myśl propozycji złożonych przez Ribbentropa Lipskiemu 24 X 1938 r. - M.P.], dałoby Führerowi możność uzyskania od narodu niemieckiego ostatecznej sankcji dla granicy polsko-niemieckiej" ${ }^{109}$. Himmler nie przepuścił okazji omawiania spraw politycznych (przede wszystkim Gdańska) również z gen. Zamorskim. Zgłosił też propozycję zorganizowania kolejnego stażu dla polskich i niemieckich oficerów policji110. Po spotkaniach w Warszawie pierwszego dnia wizyty (18 lutego) nastąpił odjazd na polowanie do Białowieży. Himmler przebywał w Polsce do 21 lutego ${ }^{111}$.

W świetle zaprezentowanych wyżej faktów istnienie współpracy polskich i niemieckich władz bezpieczeństwa nie ulega wątpliwości. Nawiązanie kontaktów nastąpiło z inicjatywy Himmlera, za pośrednictwem ambasadora Lipskiego. Zabiegi w tym kierunku strona niemiecka rozpoczęła już w maju 1933 r., jednak dopiero w 1935 r. osiągnięto z Warszawą porozumienie. Przyczyniły się do tego nie tylko deklaracja z 26 stycznia 1934 r. i poważne traktowanie zarówno w Berlinie, jak i w Warszawie zagrożenia ze strony ruchu komunistycznego, ale i zamach na ministra Pierackiego. Udzielenie pomocy przez Himmlera w tej sprawie i sugerowanie przez niego, że nawiązanie współpracy polskich i niemieckich władz bezpieczeństwa pozwoli na uniknięcie zagrożenia ze strony ruchu ukraińskiego w przyszłości bez wątpienia miały decydujące znaczenie. Ponieważ rząd polski nie zamierzał się w tej sprawie wiązać żadnym oficjalnym porozumieniem, miało ono prawdopodobnie postać gentlemen's agreement (ta forma sprzyjała jednak rozbieżnym interpretacjom: minister Ribbentrop uznawał, że oba państwa łączy „umowa policyjna”, z kolei ambasador Lipski mówił raczej o „poufnym porozumieniu”). Z tych samych względów Warszawa nie zamierzała odpowiedzieć pozytywnie na niemieckie propozycje przystąpienia do paktu antykominternowskiego, co z oczywistych względów stanowiłoby zerwanie z dotychczasową linią

109 Notatka zastępcy podsekretarza stanu z rozmowy z reichsführerem SS, 18 II 1939, w: Polskie dokumenty dyplomatyczne. Styczeń - sierpień 1939, red. S. Żerko, współpraca P. Długołęcki, Warszawa 2005, dok. 53, s. 104-107.

110 List radcy ambasady $w$ Berlinie do naczelnika Wydziału Zachodniego w sprawie wizyty reichsführera SS w Polsce, 22 II 1939, w: ibidem, dok. 54, s. 108-110.

111 AAN, KGPP, 2204, Okólnik komendanta głównego PP: program wizyty Himmlera w Polsce, 16 II 1939, k. 7; Wizyta szefa policji niemieckiej Himmlera w Polsce, „Przegląd Policyjny" 1939, 2, s. 147-148. 
polityki zagranicznej, zgodnie z którą konsekwentnie unikano wiązania się z jednym z sąsiadujących mocarstw przeciwko drugiemu.

Rozpoczętą w marcu 1935 r. wymianę informacji obie strony starały się zachować w ścisłej tajemnicy (nie zdawała sobie z nich sprawy nawet część wyższych urzędników polskiego MSZ). Ze strony polskiej za współpracę odpowiadał Henryk Kawecki z MSW, a jego delegowanie do tej działalności odbyło się po konsultacjach między MSW a MSZ, jak można przypuszczać, również za wiedzą i zgodą ministrów obu wymienionych resortów.

Wiadomo, że z polskiego MSW korespondencję przekazywano do Gestapo w Berlinie za pośrednictwem Ambasady RP. Najczęściej zawierała ona materiały propagandowe KPP (,wydawnictwa kompartii polskiej”). Nie wiemy, jakimi informacjami rewanżowała się strona niemiecka. Również sposób przekazywania przez nią korespondencji jest nieznany. Nie wiemy też, która strona była aktywniejsza w przekazywaniu informacji. Ponieważ znamy treść tylko niewielkiej części korespondencji, trudno pokusić się o jej charakterystykę. Wiadomo jednak, że dotyczyła m.in. działalności Kominternu. Przygotowana w Gestapo odpowiedź na pisma Kaweckiego w tej sprawie zdaje się sugerować, że przesłane informacje nie były dla strony niemieckiej żadnym novum. Natomiast trudna do wyjaśnienia jest motywacja przyświecająca Kaweckiemu wysyłającemu pismo z zapytaniem o niemieckie ustawy antykomunistyczne.

\section{Streszczenie}

Prezentowany tekst dotyczy kontaktów polskich i niemieckich władz bezpieczeństwa (przede wszystkim polskiego Ministerstwa Spraw Wewnętrznych i niemieckiej Tajnej Policji Państwowej) w latach 1935-1939. Nawiązanie współpracy nastąpiło z inicjatywy Heinricha Himmlera, Reichsführera SS, za pośrednictwem ambasadora RP w Berlinie Józefa Lipskiego. Zabiegi w tym kierunku strona niemiecka rozpoczęła już w maju 1933 r., jednak dopiero w 1935 r. osiągnięto z Warszawą porozumienie. Ze strony polskiej za współpracę odpowiadał Henryk Kawecki z MSW, a jego delegowanie do tej działalności odbyło się po konsultacjach między MSW a Ministerstwem Spraw Zagranicznych. Działalność ta została pokazana w szerszym kontekście, uwzględniającym stosunki polsko-niemieckie w tym czasie oraz współpracę Gestapo z policjami innych państw (nie pominięto również kontaktów między Komendą Główną Policji Państwowej a niemiecką Policją Porządkową, o ile wiązała się z omawianą tematyką).

Rozpoczętą w marcu $1935 \mathrm{r}$. wymianę informacji obie strony starały się zachować w ścisłej tajemnicy. MSW przekazywało korespondencję do Gestapo w Berlinie 
za pośrednictwem polskiej ambasady. Najczęściej zawierała ona materiały propagandowe KPP. Znana jest treść tylko niewielkiej części korespondencji, którą wymieniły obie strony, wobec czego trudno pokusić się o jej charakterystykę. Wiadomo jednak, że dotyczyła m.in. działalności Kominternu. Przygotowana w Gestapo odpowiedź na pisma Kaweckiego w tej sprawie zdaje się sugerować, że przesłane informacje nie były dla strony niemieckiej żadnym novum. Natomiast trudna do wyjaśnienia jest motywacja przyświecająca Kaweckiemu wysyłającemu pismo $\mathrm{z}$ zapytaniem o niemieckie ustawy antykomunistyczne.

Kres polsko-niemieckiej wymiany informacji w sprawie działalności komunistycznej nastąpił latem 1939 r. MSW nadało ostatnią przesyłkę adresowaną do Gestapo 13 lipca 1939 r.

\section{Contacts of Polish and German Security Authorities in the Second Half of the 1930s (the Question of Communist Threat)}

The present article deals with the communications between the Polish and German security authorities (mainly the Polish Ministry of Internal Affairs and German Secret State Police) between 1935 and 1939. The cooperation was established on the initiative of Reichsführer SS Heinrich Himmler, through the agency of Polish ambassador in Berlin Józef Lipski. The first steps towards collaboration the German side took in May 1933, but it was not until 1935 that an agreement with Warsaw was reached. On the Polish side, the cooperation was managed by Henryk Kawecki from the Ministry of Internal Affairs, delegated to this task after consultations between the Ministries of Internal and Foreign Affairs. The operation was presented by the author in a broad context of German-Polish relations, including the Gestapo cooperation with police forces of other states (without the omission of contacts between the Polish National Police Headquarters and the German Order Police, Ordnungspolizei, as much as they related to the analysed subject).

The information exchange began in March 1935, and both parties sought to keep it secret. The Ministry of Internal Affairs sent despatches to the Gestapo in Berlin through the Polish Embassy. Most often, they contained propagandist materials of the Polish Communist Party. We know only a small part of the correspondence exchanged by both parties, it is, therefore, difficult to present its deep characteristics. We know, however, that a part of it referred to, among other things, the operations of the Comintern. A response to Kawecki's letters prepared in the Gestapo on this matter seems to suggest that the information was nothing new for the German side. What is difficult to explain was Kawecki's motives when sending a letter with a question about the German anti-communist regulations. The end of the German-Polish exchange of information about communistic activities came in the summer of 1939. The Ministry of Internal Affairs sent the last mail to the Gestapo on 13 July 1939. 


\section{Bibliografia}

Akten zur deutschen auswärtigen Politik, seria D, t. 5: Polen, Südosteuropa, Lateinamerika, Klein- und Mittelstaaten, Juni 1937 - März 1939, Vandenhoeck \& Ruprecht, Impr. Nationale, Göttingen-Baden-Baden 1953.

Borejsza Jerzy Wojciech, Rzym a wspólnota faszystowska. O penetracji faszyzmu włoskiego w Europie Środkowej, Południowej i Wschodniej, Książka i Wiedza, Warszawa 1981.

Bornschein Joachim, Gestapo-Müller. Technokrata terroru, Bellona, Warszawa 2009.

Borodziej Włodzimierz, Terror i polityka. Policja niemiecka a polski ruch oporu w GG 1939-1944, Pax, Warszawa 1985.

Broszat Martin, 200 lat niemieckiej polityki wobec Polski, Volumen, Warszawa 1999.

Cimek Henryk, Kieszczyński Lucjan, Komunistyczna Partia Polski 1918-1938, Książka i Wiedza, Warszawa 1984.

Daluege Kurt, Nationalsozialistischer Kampf gegen das Verbrechertum, Zentralverlag der NSDAP, München 1936.

Diariusz i teki Jana Szembeka (1935-1945), t. 4, oprac. Józef Zarański, The Polish Institute and Sikorski Museum, London 1972.

The Diary of Georgi Dimitrov 1933-1949, oprac. Ivo Banac, Yale University Press, New Haven-London 2003.

Diels Rudolf, Lucifer ante Portas. Zwischen Severing und Heydrich, Interverlag, Zürich 1949.

Dokumenty z dziejów polskiej polityki zagranicznej 1918-1939, t. 2: 1933-1939, red. Tadeusz Jędruszczak, Maria Nowak-Kiełbikowa, Pax, Warszawa 1996.

Hory Andràs, „Martwa placówka”. Wspomnienia i korespondencja posła Królestwa Węgier w Warszawie 1935-1939, IPN - KŚZpNP, Warszawa 2017.

Gadomski Bogdan, Biografia agenta. Józef-Josek Mützenmacher (1903-1947), Wydawnictwo Tedson, Warszawa 2009.

Grünberg Karol, SS - czarna gwardia Hitlera, Książka i Wiedza, Warszawa 1975.

Hempel Adam, Pogrobowcy klęski. Rzecz o policji "granatowej” w Generalnym Gubernatorstwie 1939-1945, PWN, Warszawa 1990.

Jacobsen Hans-Adolf, Nationalsozialistische Aussenpolitik 1933-1938, Metzner, Frankfurt am Main-Berlin 1968.

Kornat Marek, Polityka zagraniczna Polski 1938-1939. Cztery decyzje Józefa Becka, Wydawnictwo Oskar, Muzeum II Wojny Światowej, Gdańsk 2012.

Kowalski Józef, Komunistyczna Partia Polski 1935-1938. Studium historyczne, Książka i Wiedza, Warszawa 1975.

Król Eugeniusz Cezary, Polska i Polacy w propagandzie narodowego socjalizmu w Niemczech 1919-1945, ISP PAN, Rytm, Warszawa 2005.

Landau Ludwik, Kronika lat wojny i okupacji, t. 1: Wrzesień 1939 - listopad 1940, do dr. przygot. Zbigniew Landau, Jerzy Tomaszewski, PWN, Warszawa 1962.

Lipski Józef, Diplomat in Berlin 1933-1939. Papers and Memoirs of Józef Lipski, Ambassador of Poland, oprac. Wacław Jędrzejewicz, Columbia University Press, New York-London 1968.

Litwiński Robert, Kordian Józef Zamorski. „Granatowy” generał, Wydawnictwo UMCS, Lublin 2018. 
Litwiński Robert, Korpus policji w II Rzeczypospolitej. Służba i życie prywatne, Wydawnictwo UMCS, Lublin 2010.

Ławnik Józef, Represje policyjne wobec ruchu robotniczego 1918-1939, Książka i Wiedza, Warszawa 1979.

Maciejewski Marek, Stosunek Adolfa Hitlera do spraw polskich od zarania nazizmu do jego upadku, „Studia nad Autorytaryzmem i Totalitaryzmem” 36, 2014, 2, s. 35-68.

Majewski Marcin, Jerzy Krzymowski - ostatni naczelnik Wydziału Bezpieczeństwa MSW (1937-1939), w: Sekretna Wojna II. Z dziejów kontrwywiadu II RP (1914) 1918-1945 (1948), red. Zbigniew Nawrocki, Zysk i S-ka, Poznań 2015, s. 535-562.

Makowski Julian, Prawo międzynarodowe, cz. 1, Drukarnia Wł. Łazarskiego, Warszawa 1930.

Michalka Wolfgang, Ribbentrop und die deutsche Weltpolitik 1933-1940. Außenpolitische Konzeptionen und Entscheidungsprozesse im Dritten Reich, Wilhelm Fink, München 1980.

Misiuk Andrzej, Generał dywizji WP (generalny inspektor PP) Józef Kordian Zamorski. Komendant główny Policji Państwowej (25 I 1935 - IX 1939), w: Komendanci główni polskiej policji (1918-2009), red. Piotr Majer, Wydawnictwo Wyższej Szkoły Policji, Szczytno 2009, s. 63-65.

Misiuk Andrzej, Policja Państwowa 1919-1939. Powstanie, organizacja, kierunki działania, PWN, Warszawa 1996.

Misstrauische Nachbarn. Deutsche Ostpolitik 1919/1970. Dokumentation und Analyse, oprac. Hans-Adolf Jacobsen, współpraca Wilfried Bredow, Droste, Düsseldorf 1970.

Mycielska Dorota, Zawadzki Jarosław Maciej, Senatorowie zamordowani, zaginieni, zmarli w latach II wojny światowej, Kancelaria Senatu, Warszawa 2009.

Pepłoński Andrzej, Policja Państwowa w systemie organów bezpieczeństwa Drugiej Rzeczypospolitej, Wydawnictwo Wyższej Szkoły Policji, Szczytno 1991.

Pepłoński Andrzej, Współpraca Policji Państwowej z policjami innych państw w okresie międzywojennym, w: 225 lat policji w Polsce, t. 1: Geneza i ewolucja policji, red. Piotr Majer, Martyna Seroka, Wydział Prawa i Administracji Uniwersytetu Warmińsko-Mazurskiego, Olsztyn 2017, s. 183-197.

Polskie dokumenty dyplomatyczne. 1934, red. Stanisław Żerko, współpraca Piotr Długołęcki, PISM, Warszawa 2014.

Polskie dokumenty dyplomatyczne. 1937, red. Jan Stanisław Ciechanowski, współpraca Piotr Długołęcki, PISM, Warszawa 2012.

Polskie dokumenty dyplomatyczne. 1938, red. Marek Kornat, współpraca Piotr Długołęcki, Maria Konopka-Wichrowska, Marta Przyłuska, PISM, Warszawa 2007

Polskie dokumenty dyplomatyczne. Styczeń - sierpień 1939, red. Stanisław Żerko, współpraca Piotr Długołęcki, PISM, Warszawa 2005.

Pryt Karina, Befohlene Freundschaft. Die deutsch-polnischen Kulturbeziehungen 1934-1939, Fibre, Osnabrück 2010.

Przegiętka Marcin, Podpułkownik żandarmerii Hans Köllner, jeden z organizatorów Policji Polskiej tzw. granatowej w Generalnym Gubernatorstwie, w: Polnische Polizei im Generalgouvernement. Policja Polska ,granatowa" w Generalnym Gubernatorstwie w latach 1939-1945, red. Tomasz Domański, Edyta Majcher-Ociesa, IPN - KŚZpNP, Warszawa-Kielce 2019. 
Ryszka Franciszek, Państwo stanu wyjątkowego. Rzecz o systemie państwa i prawa Trzeciej Rzeszy, Ossolineum, Wrocław-Warszawa-Kraków 1985.

Sacewicz Karol, Centralna prasa Polski podziemnej wobec komunistów polskich 1939-1945, IPN - KŚZpNP, Warszawa 2009.

Sacewicz Karol, Komunizm i antykomunizm w II Rzeczypospolitej. Państwo - społeczeństwo - partie, Instytut Historii i Stosunków Międzynarodowych Uniwersytetu Warmińsko-Mazurskiego, Olsztyn 2016.

Schmitz-Berning Cornelia, Vokabular des Nationalsozialismus, De Gruyter, Berlin-New York 1998.

Seeger Andreas, Vom bayerischen „Systembeamten” zum Chef der Gestapo. Zur Person und Tätigkeit Heinrich Müllers (1900-1945), w: Die Gestapo - Mythos und Realität, red. Gerhard Paul, Klaus-Michael Mallmann, Wissenschaftliche Buchgesellschaft, Darmstadt 1995, s. 255-267.

Skóra Wojciech, Niemiecki aspekt sprawy zabójstwa ministra Bronisława Pierackiego, „Słupskie Studia Historyczne” 5, 1997, s. 119-137.

Stanisławska Stefania, Warszawska filia antykominternu. Nie opublikowane dokumenty MSZ Polski w sprawie tzw. Ekspozytury Kominternu w Pradze, w: Studia z najnowszych dziejów powszechnych, t. 3, red. Karol Lapter i in., PWN, Warszawa 1960, s. 241-298.

Torzecki Ryszard, Kwestia ukraińska w polityce III Rzeszy (1933-1945), Książka i Wiedza, Warszawa 1972.

Wiaderny Bernard, Hans Adolf von Moltke. Eine politische Biographie, Ferdinand Schöningh, Paderborn 2017.

Wojciechowski Marian, Stosunki polsko-niemieckie 1933-1938, Instytut Zachodni, Poznań 1980.

Zackiewicz Grzegorz, Polska myśl polityczna wobec systemu radzieckiego 1918-1939, Arcana, Kraków 2004.

Żeleński Władysław, Jeszcze o zabójstwie Pierackiego i rozrachunkach polsko-ukraińskich, „Zeszyty Historyczne” 1978, 46, s. 129-183.

Żerko Stanisław, Polska, Niemcy i geneza II wojny światowej, „Przegląd Zachodni” 2009, 2, s. 3-32.

Żerko Stanisław, Stosunki polsko-niemieckie 1938-1939, Instytut Zachodni, Poznań 1999.

Biogram: Marcin Przegiętka, dr nauk humanistycznych w zakresie historii, pracownik Biura Badań Historycznych Instytutu Pamięci Narodowej w Warszawie. Interesuje się stosunkami polsko-niemieckimi w okresie międzywojennym oraz niemiecką okupacją ziem polskich podczas II wojny światowej, w szczególności rolą niemieckiego aparatu terroru; kontakt: marcin.przegietka@gmail.com. 